\title{
Metabolites of Arachidonic Acid in the Nervous System of Aplysia: Possible Mediators of Synaptic Modulation
}

\author{
Daniele Piomelli, Eli Shapiro, Steven J. Feinmark, and James H. Schwartz \\ Department of Pharmacology and The Howard Hughes Medical Institute, Center for Neurobiology and Behavior, \\ Columbia University, New York, New York 10032
}

Release of arachidonic acid from membrane phospholipids is receptor-mediated and might generate second messengers in neurons. We tested this idea using the simple nervous system of the marine mollusk, Aplysia californica. Ap/ysia neural components metabolize arachidonic acid through lipoxygenase and cyclo-oxygenase pathways. We identified 2 major lipoxygenase products, 12- and 5-hydroxyeicosatetraenoic acids (12-HETE and 5-HETE), and 2 cyclo-oxygenase products, $\mathrm{PGE}_{2}$ and $\mathrm{PGF}_{2 \alpha^{*}}$. These metabolites of arachidonic acid are formed in synaptosomes, as well as in identified nerve cell bodies, indicating that both lipoxygenase and cyclo-oxygenase pathways are active within neurons. Application of the modulatory neurotransmitter histamine to cerebral ganglia that had been labeled with ${ }^{3} \mathrm{H}$ arachidonic acid induced the formation of ${ }^{3} \mathrm{H}-12-\mathrm{HETE}$. This response was inhibited by the histamine antagonist cimetidine. Furthermore, release of radioactive 5-HETE and 12-HETE was observed after intracellular stimulation of the histaminergic cell $\mathrm{C}_{2}$ in cerebral ganglia labeled with ${ }^{3} \mathrm{H}$ arachidonic acid. Cimetidine also inhibited this response. Application of serotonin or stimulation of the giant serotonergic cell (GCN) in the cerebral ganglion did not cause detectable amounts of the labeled eicosanoids to be released. We found that intracellular stimulation of putative histaminergic neurons in the L32 cluster of the abdominal ganglion, which produces presynaptic inhibition in $L 10$ neurons, also elicited the release of ${ }^{3} \mathrm{H}-12-\mathrm{HETE}$ and ${ }^{3} \mathrm{H}-\mathrm{PGE}_{2}$. Thus, for the first time we provide evidence that synaptic stimulation promotes turnover of arachidonic acid in neurons. We suggest that metabolites of arachidonic acid are likely to participate in some postsynaptic responses to histamine and may be second messengers for presynaptic inhibition.

Although biochemical actions of neurotransmitters were recognized soon after Sutherland discovered cAMP (Sutherland and Rall, 1960), for many years the predominant mechanism of synaptic transmission was thought to be direct: the binding of neurotransmitter to ionophoric receptors, causing rapid changes in membrane conductance. Because of recent work on

\footnotetext{
Received Dec. 31, 1986; revised May 13, 1987; accepted May 14, 1987

We thank Drs. F. Belardetti, S. Siegelbaum, D. Sweatt, and A. Volterra for reading the manuscript critically, and Robin Tewes for preparing the figures. S.J.F. is an investigator of the New York Heart Association.

Correspondence should be addressed to James H. Schwartz, M.D. Ph D. Howard Hughes Medical Institute, Research Annex/Room 708, 722 West 168th Street, New York, NY 10032

Copyright (C) 1987 Society for Neuroscience $0270-6474 / 87 / 113675-12 \$ 02.00 / 0$
}

transmembrane transduction (see Stryer and Bourne, 1986), it seems likely that, more commonly, neurotransmitters act indirectly through the generation of intracellular second messengers. Attention has been focused primarily on the receptor-stimulated activation of adenylate cyclase and phospholipase C. Release of arachidonic acid from membrane phospholipids also might be mediated by receptors in neurons and could represent the transducing event for as-yet unidentified second messenger cascades (Wolfe, 1982). In non-neuronal mammalian cells, free arachidonate is released through receptor-mediated reactions triggered by hormones, autacoids, and growth factors; once released from the membrane, the fatty acid is rapidly metabolized to a family of bioactive products (the eicosanoids), many of which have been implicated in either intracellular or intercellular signaling (Needleman et al., 1986).

Formation of cyclo-oxygenase products, the prostaglandins $\mathrm{PGD}_{2}, \mathrm{PGE}_{2}$, and $\mathrm{PGF}_{2 \alpha}$, has been shown in neural tissue (Wolfe, 1982). In addition, Lindgren et al. (1984) and Adesuyi et al. (1985) have demonstrated lipoxygenase activities in mammalian brain, as indicated by the formation of 12- and 5-hydroxyeicosatetraenoic acids (HETE) and the peptide-containing leukotrienes. Despite these biochemical advances, direct evidence that eicosanoids play a role in neuronal function has been difticult to obtain because of the heterogeneity of nervous tissue and the small size of vertebrate nerve cells. These obstacles are minimized in Aplysia and other invertebrates that offer the experimental advantage of relative simplicity and large, identifiable neurons with known properties

In this study, we examined the arachidonic acid cascade in the nervous system of Aplysia. We first found that arachidonic acid is a significant constituent of neural phospholipids. Then we showed that arachidonic acid is metabolized through both lipoxygenase and the cyclo-oxygenase pathways. In order to provide evidence that metabolism occurs within neurons, we next examined the formation of eicosanoids in isolated neuronal cell bodies and in synaptosomes. Experiments with histamine, or intracellular stimulation of the histaminergic neuron $\mathrm{C} 2$ or of putatively histaminergic cells in the L32 cluster, indicate that physiologically appropriate stimuli can evoke the metabolism of arachidonic acid, presumably through activation of postsynaptic receptors that are linked to a phospholipase.

Some of these results have been published previously as an abstract (Piomelli et al., 1986).

\section{Materials and Methods}

Aplysia californica, weighing 70-200 gm (Howard Hughes Medical Institute Mariculture Resource Facility, Woods Hole Oceanographic Institution, Woods Hole, MA and Marinus, Sand City, CA), were kept in 


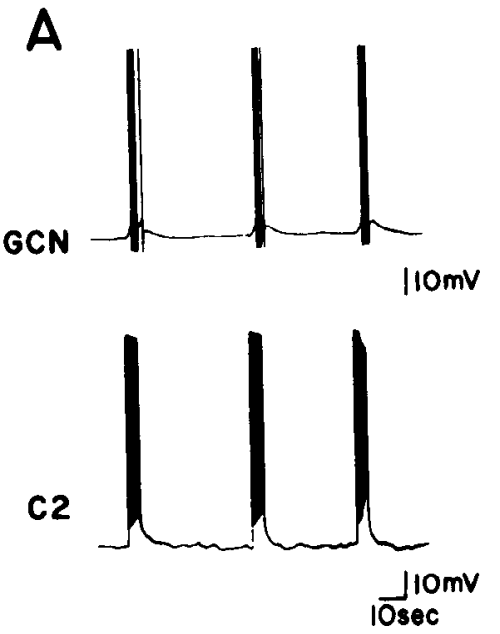

B
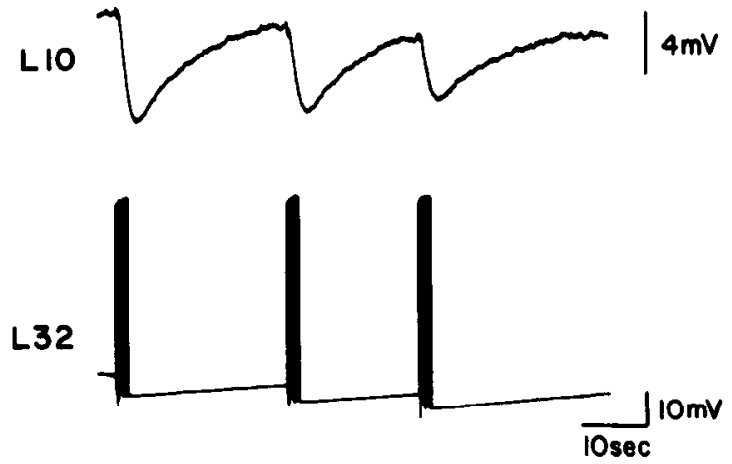

Figure 1. Stimulation of identified neurons in Aplysia. A, C2 cells are a bilaterally symmetrical pair of histaminergic neurons in the cerebral ganglion. Each makes a slow excitatory connection to the ipsilateral GCN (see McCaman and Weinreich, 1985, for cell map). C2 cells (lower trace) were stimulated with $3 \mathrm{DC}$ pulses of 2 sec duration, each producing 40 spikes and a suprathreshold slow excitatory synaptic potential onto GCN (top trace). (This response is not blocked by cimetidine.) After the stimulation, the bath was assayed for ${ }^{3} \mathrm{H}$-arachidonic acid metabolites. HPLC chromatograms from this experiment are shown in Figure 8. B, L32 cells, which are putatively histaminergic and are clustered in the left abdominal hemiganglion, make inhibitory connections with L10 and LUQ cells and a dual-action fast-excitatory/slow-inhibitory connection with L14 cells (see Byrne, 1980a, b, for cell map; Kretz et al., 1986a). L32 cells were stimulated with 3 depolarizing DC pulses of 2 sec duration, each producing 40 spikes in L32 (lower trace), and a slow inhibitory potential in $\mathrm{L} 10$ (upper trace). After the stimulation the bath was assayed for ${ }^{3} \mathrm{H}$-arachidonic acid metabolites. The HPLC chromatograms from this experiment are shown in Figure 9.

aquaria at $15^{\circ} \mathrm{C}$. Ganglia with nerves attached were removed through an incision in the foot from animals anesthetized by injection of a volume of isotonic $\mathrm{MgCl}_{2}$ corresponding to half the body weight. All procedures were performed at $15^{\circ} \mathrm{C}$ unless stated otherwise.

\section{Intracellular stimulation of identified neurons}

Cerebral or abdominal ganglia were pinned to silicone plastic (Sylgard; Dow Chemical Corp., Midland, MI) in a chamber containing $0.3-0.4$ $\mathrm{ml}$ of a supplemented artificial seawater (Eisenstadt et al., 1973). Cerebral ganglia were pinned dorsal side up to allow access to the identified histaminergic cell $\mathrm{C} 2$ and to the serotonergic giant cerebral neuron (GCN). Abdominal ganglia were pinned ventral side up to allow access to $\mathrm{L} 32$ and their follower cells. The 2 bilaterally symmetrical $\mathrm{C} 2$ cells and the ipsilateral GCNs were exposed by partial removal of the overlying connective tissue sheath. Abdominal ganglia were desheathed to expose the cell body of L10 and the neurons in the L32 cluster. Ganglia were then incubated overnight in the seawater containing ${ }^{3} \mathrm{H}$-arachidonic acid $(25 \mu \mathrm{Ci} / \mathrm{ml}, 135 \mathrm{Ci} / \mathrm{mmol}$ ) (Amersham, Arlington Heights, IL).

After incubation, the ganglia were washed extensively with seawater to remove any unincorporated ${ }^{3} \mathrm{H}$-arachidonic acid. $\mathrm{C} 2$ or $\mathrm{L} 32$ cells were impaled with standard intracellular glass-capillary microelectrodes (10-20 $\mathrm{m} \Omega$ resistance, filled with $2 \mathrm{M}$ potassium citrate) connected to bridge circuits for recording intracellularly and passing current. $\mathrm{C} 2$ and GCN were identified by their characteristic size, position, and spontaneous activity, and by the presence of a slow, excitatory synaptic potential produced by $\mathrm{C} 2$ on to GCN (Fig. 1A). Neurons in the L32 cluster were identified by their size, location, spontaneous activity, and their ability to produce a slow, dual-action PSP in L14 cells $(n=6)$; in some instances, $\mathrm{L} 32$ neurons were identified by their ability to produce a slow, inhibitory synaptic potential in L10 $(n=5)$ (Fig. 1B) (Byrne, 1980a, b; Kretz et al., 1986a). In each experiment, follower cells were impaled first, and a $0.2 \mathrm{ml}$ sample of the bath was taken before C2 or L32 was impaled. C2 or L32 was stimulated with intracellular current pulses to produce spikes and release their transmitter. In most experiments, the stimulation protocol consisted of delivering 3 depolarizing pulses lasting $2.5-5 \mathrm{sec}$ at $30 \mathrm{sec}$ intervals, cach of which clicted 25-50 spikes (Fig. 1). To control for the effects of depolarization and spike activity in the GCN follower cell, as well as for any nonspecific effects of intracellular stimulation, we stimulated GCN alone, using 3 intracellular current pulses to produce 20 spikes each at 1 min intervals. In another experiment, we controlled for the postsynaptic inhibitory responses of L10 and L14 by hyperpolarizing these cells by injecting current. After the stimulation, $0.2 \mathrm{ml}$ of the bath was collected for assaying metabolites of arachidonic acid. In other experiments with the histamine antagonist cimetidine, ganglia were incubated for $10 \mathrm{~min}$ at $10^{-4} \mathrm{M}$ before the cell was stimulated. After washing the cimetidine out, we waited $10 \mathrm{~min}$ before stimulating again.

\section{Preparation of nervous tissue for biochemical analysis}

Isolated ganglia. Intact ganglia were labeled for $2 \mathrm{hr}$ or overnight with ${ }^{32} \mathrm{P}_{\mathrm{i}}$ (carrier-free, $25 \mu \mathrm{Ci} / \mathrm{ml}$ ) and with ${ }^{3} \mathrm{H}$-ethanolamine, ${ }^{3} \mathrm{H}$-choline, ${ }^{3} \mathrm{H}$ inositol, or ${ }^{14} \mathrm{C}$-serine (each at $2 \mu \mathrm{Ci} / \mathrm{ml}$ ), both from Amersham.

Neural components. Connective tissue sheaths were removed by dissection from central ganglia, and the neural components (cell bodies and neuropil) were placed in the supplemented seawater. In some experiments, the isolated neural components were incubated for $2 \mathrm{hr}$ or overnight in seawater $(0.2 \mathrm{ml})$ containing $2.5-25 \mu \mathrm{Ci} / \mathrm{ml}^{3} \mathrm{H}$-arachidonic acid (Amersham; sp act, $85-135 \mathrm{Ci} / \mathrm{mmol}$ ).

Isolated cell body of $R 2$. Pinned abdominal ganglia from specimens weighing $50-70 \mathrm{gm}$ were incubated for $50 \mathrm{~min}$ in seawater containing trypsin (Sigma, St. Louis, MO; type IIIS, $4 \mathrm{mg} / \mathrm{ml}$ ) to facilitate removal of the sheath for exposing underlying neurons (Connor et al., 1986). The trypsin-containing bathing solution was then removed and the ganglia washed with seawater containing soybean trypsin inhibitor (Sigma), followed by seawater. The isolated cell body of the cholinergic neuron $\mathrm{R} 2$ was incubated for $2 \mathrm{hr}$ in seawater $(50 \mu \mathrm{l})$ containing ${ }^{3} \mathrm{H}$-arachidonic acid $(25 \mu \mathrm{Ci} / \mathrm{ml})$ and washed gently by successively diluting the bath. The cell was mechanically stimulated by agitating the $50 \mu$ l bath by pipetting 1 or 2 times during a period of $1 \mathrm{~min}$. Phospholipases are sensitive to mechanical stimulation (Van den Bosch, 1980); because of the small amount of material, it was necessary to stimulate the metabolism of arachidonic acid to ensure detection of the labeled eicosanoids. Metabolites were analyzed after an equal volume of methanol was added.

Aplysia synaptosomes. Chin et al. (1985; and unpublished observations) have developed a membrane preparation from Aplysia ganglia enriched in isolated nerve terminals (synaptosomes) that retains the ability to release transmitter in a $\mathrm{Ca}^{2+}$ - and depolarization-dependent manner. Briefly, central nervous systems from 4 animals, trimmed of extrancous conncetive tissuc, were blotted dry and then homogenized at $4^{\circ} \mathrm{C}$ in $0.8 \mathrm{ml}$ of $1.1 \mathrm{M}$ sucrose. After we removed large chunks of connective tissue, we placed the homogenate in a $15 \mathrm{ml}$ centrifuge tube, overlaying it with $1.0 \mathrm{ml}$ of $0.8 \mathrm{M}$ sucrose, and centrifuged for $10 \mathrm{~min}$ at $1000 \times g$. The $0.8 \mathrm{M}$ layer was then removed by aspiration, diluted with 3 vol of $\mathrm{Ca}^{2+}$-free seawater $\left(465 \mathrm{mM} \mathrm{NaCl}, 55 \mathrm{mM} \mathrm{MgCl}_{2}, 10 \mathrm{~mm}\right.$ $\mathrm{KCl}, 10 \mathrm{~mm}$ Tris- $\mathrm{HCl}, \mathrm{pH} 7.4$ ), and centrifuged again for $10 \mathrm{~min}$ at 
$10,000 \times g$. The pellet resulting from this centrifugation (about $0.5 \mathrm{mg}$ protein), which is enriched in pinched-off synaptic terminals, as judged by biochemical and morphological criteria, was divided into 3 parts, and each was gently resuspended in $0.1 \mathrm{ml}$ seawater containing ${ }^{3} \mathrm{H}$ arachidonic acid $(5 \mu \mathrm{Ci} / \mathrm{ml})$. After $2 \mathrm{hr}$, the synaptosomes were sedimented by low-speed centrifugation and resuspended in $0.1 \mathrm{ml}$ seawater; then arachidonic acid metabolism was mechanically stimulated for 1 min by stirring with a pipette.

\section{Analytical methods}

Values are given as means \pm SEM.

Extraction of lipid. Neural components were homogenized at $0^{\circ} \mathrm{C}$ in $0.1 \mathrm{ml}$ of $\mathrm{Ca}^{2+}$-free seawater containing $2 \mathrm{~mm}$ EGTA. The homogenate was extracted twice with hexane/isopropanol $(3: 2, \mathrm{vol} / \mathrm{vol})$ for $30 \mathrm{~min}$ at room temperature; the organic phases were dried under a stream of $\mathrm{N}_{2}$ and reconstituted in $0.1 \mathrm{ml}$ of hexane prior to further analysis.

Extraction of eicosanoids. Samples of bath solutions were acidified to $\mathrm{pH} 3.5$ with formic acid and extracted twice with 5 volumes of chloroform. The organic phases were combined, dried, and reconstituted in methanol $(0.1 \mathrm{ml})$. Alternatively, neural tissue homogenates were shaken with 2 volumes of cold acetone and centrifuged. The supernatant

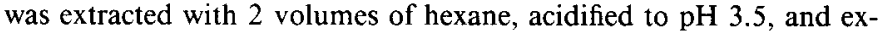
tracted again with 5 volumes of diethyl ether. The ether phase was dried under $\mathrm{N}_{2}$ and reconstituted in hexane/isopropanol/acetic acid (98:2:0.1; $0.25 \mathrm{ml}$ ) for purification by high-performance liquid chromatography (HPLC).

Thin-layer chromatography (TLC). TLC was performed on silica gel $G$ plates (Analtech, Newark, DE) that had been activated for $30 \mathrm{~min}$ at $80^{\circ} \mathrm{C}$. The major lipid classes were separated in hexane/ethyl ether/ acetic acid/methanol (85:20:2:4; solvent system $\mathrm{A})$. Phospholipids were separated in chloroform/methanol $/ 20 \%$ aqueous methylamine $600: 36$ : 10; system B). The migration of lipid standards was determined by staining with 5\% phosphomolybdic acid in ethanol.

Gas-chromatography-mass spectrometry (GC/MS). Total lipid extracts were subjected to transmethylation with $12 \%$ boron trifluoride in methanol for $1 \mathrm{hr}$ at $70^{\circ} \mathrm{C}$. The reaction mixture was extracted twice with an equal volume of hexane, and the organic layer dried under $\mathrm{N}_{2}$ and reconstituted in $10 \mu \mathrm{l}$ hexane for analysis. GC/MS of the fatty acid methyl esters was carried out on a Hewlett-Packard 5985 (Palo Alto, CA) equipped with a glass column packed with $10 \%$ Silar $10 \mathrm{CP}$. Helium was the carrier gas, with a temperature program from 160 to $220^{\circ} \mathrm{C}$ at a rate of $10^{\circ} \mathrm{C} / \mathrm{min}$. Quantitative $\mathrm{GC}$ analysis was performed on a Hewlett-Packard 5840 GC on a SP 2340 fused silica-capillary column (30 $\mathrm{m} \times 0.32 \mathrm{~mm}$ I.D.; Supelco, Bellefonte, PA). Samples were injected in the split mode (ratio, 100:1), and helium was the carrier $(1 \mathrm{ml} / \mathrm{min}$ ). The injector and flame ionization detector were kept at $230^{\circ} \mathrm{C}$. In other experiments, we performed these determinations on individual phospholipid classes after they had been separated by TLC.

GC/MS of the hydroxy acid derivatives was carried out on a HewlettPackard 5987A. For analysis, the hydroxy acids were converted to the corresponding methyl ester trimethylsilyl ether (Me-TMS) derivatives by trcatment with cxcess ethereal diazomethane $(10 \mathrm{~min}$ at room temperature). The solvent was evaporated, and the dry residue incubated with bis(trimethylsilyl) trifluoroacetamide (BSFTA)/acetonitrile (1:1;50 $\mu 1)$, for $15 \mathrm{~min}$ at $65^{\circ} \mathrm{C}$. Samples were dried under $\mathrm{N}_{2}$ and reconstituted in hexane for analysis. To prepare the pentafluorobenzyl (PFB) esters, samples were incubated with pentafluorobenzyl bromide $(35 \%$ in $10 \mu \mathrm{l}$ acetonitrile) and diisopropylethylamine $(10 \mu \mathrm{l}$ diluted with $30 \mu \mathrm{l}$ acetonitrile) for $10 \mathrm{~min}$ at room temperature. The TMS derivatives were prepared after drying as described above. GC/MS analysis was performed on an HP-1 capillary column ( $5 \mathrm{~m}$; Hewlett-Packard) using helium as carrier gas. For electron impact analyses of the Me-TMS derivatives, we used a temperature program from 150 to $250^{\circ} \mathrm{C}$ at a rate of $30^{\circ} \mathrm{C} / \mathrm{min}$. The injector was kept at $250^{\circ} \mathrm{C}$ and the source at $200^{\circ} \mathrm{C}$. Carrier flow was regulated by a constant head pressure of $52 \mathrm{kPa}$. Chemical ionization analysis of the PFB-TMS derivatives was carried out using methane as ionizing gas (source pressure approximately $2 \times 10^{-4}$ Torr). The injector was kept at $250^{\circ} \mathrm{C}$ and the source at $150^{\circ} \mathrm{C}$. Oven temperature was kept for 1 min at $60^{\circ} \mathrm{C}$ and then raised to $320^{\circ} \mathrm{C}$ at a rate of $30^{\circ} \mathrm{C} / \mathrm{min}$.

$H P L C$. HETE were purified from unextracted bath samples on a Novapak $\mathrm{C} 18$ column eluted isocratically with methanol/water/acetic acid (system I, 73:27:0.1) monitored at $\mathrm{A}_{235} ; 30 \mathrm{sec}$ fractions were collected and counted by liquid scintillation. In some experiments, fractions corresponding to 12 -HETE were combined and reduced to dryness.
Table 1. Fatty acids of total lipids in Aplysia nervous system

\begin{tabular}{lr} 
Fatty acid & $\begin{array}{l}\text { Relative ab } \\
\text { (area \%) }\end{array}$ \\
\hline $14: 0$ & $12.2 \pm 6.2$ \\
$16: 0$ & $10.4 \pm 3.9$ \\
$18: 0$ & $10.4 \pm 3.9$ \\
$18: 1$ & $9.8 \pm 1.6$ \\
$18: 2$ & $5.3 \pm 3.2$ \\
$20: 1^{a}$ & $4.3 \pm 1.2$ \\
$20: 2$ & $5.5 \pm 1.9$ \\
$20: 4$ & $9.9 \pm 1.5$ \\
$20: 5$ & $2.9 \pm 1.5$ \\
$22: 2$ & $4.9 \pm 1.3$ \\
$22: 4$ & $24.3 \pm 5.9$ \\
$22: 6$ & $4.2 \pm 3.3$ \\
Others & $10.7 \pm 4.1$
\end{tabular}

Neural lipids were subjected to transmethylation and the fatty acid methyl esters identified by GC/MS. Quantitative analysis was performed by GC. The area of each peak on the chromatogram was quantified by a Hewlett-Packard integrator. which also normalized these values to the total areas of all of the peaks. Fatty acid nomenclature: the first number refers to the number of carbon atoms in the chain and the second to the number of double bonds. Arachidonic acid is $20: 4$ others indicate unidentified derivatives. Values are expressed as means \pm SEM $(n=4)$.

${ }^{a}$ May contain traces of $18: 3$.

The residue was treated with an excess of ethereal diazomethane and analyzed by normal-phase HPLC on a Silicar LC Si column $(250 \times 4.6$ $\mathrm{mm}$; Supelco), which was eluted with hexane/isopropanol/acetic acid (99.5:0.5:0.1) at a flow rate of $1.5 \mathrm{ml} / \mathrm{min}$. Unextracted bath samples were also analyzed for prostaglandins by reversed-phase HPLC on a Novapak C 18 column, eluted isocratically with a mobile phase of acetonitrile/water/acetic acid (system II, 26:74:0.1) at a flow rate of 2.5 or $2.0 \mathrm{ml} / \mathrm{min}$ (Eling et al., 1982). Retention times of the prostaglandins were obtained with tritium-labeled $\mathrm{PGE}_{2}, \mathrm{PGD}_{2}, 6$-keto-PGF $\mathrm{I}_{a}$, thromboxane $\mathbf{B}_{2}$, and $\mathrm{PGF}_{2 x}$ (New England Nuclear). For spectral and $\mathrm{GC}$ / MS analysis, 12-HETE was purified from ether extracts by normalphase HPLC on a Silicar LC Si column, eluted with hexane/isopropanol/ acetic acid $(98: 2: 0.1,1 \mathrm{ml} / \mathrm{min})$. This system separates all monohydroxy acid isomers (12-, 5-, 8-, 9-, 11-, 15-, and 13-HETE). Ultraviolet absorbance was monitored continuously, using a photodiode array detector (Hewlett-Packard).

Radioimmunoassay. In some experiments, intact, isolated ganglia were incubated for $30 \mathrm{~min}$ with unlabeled arachidonic acid $(15 \mu \mathrm{M})$ in seawater $(0.2 \mathrm{ml})$ to ensure production of adequate amounts of the metabolites for assay. The bath was fractionated by reversed-phase HPLC to purify either the hydroxy acids or the prostaglandins. HPLC fractions were evaporated to dryness and reconstituted in Dulbecco's phosphate-buffered saline (Gibco, Grand Island, NY) immediately before the assay. For assaying 12-HETE, the fractions were dried, reconstituted in methanol, and subjected to further purification by reversedphase HPLC (system I). Kits from Seragen (Boston, MA) were used to assay 5-HETE, 12-HETE, $\mathrm{PGE}_{2}$, 6-keto-PGF ${ }_{1 \alpha}$, and $\mathrm{PGF}_{2 \alpha}$.

Fate of exogenous ${ }^{3} \mathrm{H}-12-H E T E$. Isolated neural components were incubated for $10 \mathrm{~min}$ in seawater $(0.25 \mathrm{ml})$ containing $0.25 \mu \mathrm{Ci} / \mathrm{ml}{ }^{3} \mathrm{H}$ 12-HETE (New England Nuclear; sp act, $225 \mathrm{Ci} / \mathrm{mmol}$ ). Samples of the bath, diluted with methanol, were analyzed by reversed-phase HPLC (solvent system I). Phospholipids were extracted from tissue and separated into classes by TLC using solvent system B. In other experiments, the extracts were dried and the residue saponified for $1 \mathrm{hr}$ in methanolic $\mathrm{KOH}$ (methanol $/ 50 \% \mathrm{KOH}, 3 / 0.2 \mathrm{vol} / \mathrm{vol}$ ) at $70^{\circ} \mathrm{C}$. After cooling, water was added and the $\mathrm{pH}$ adjusted to 3.5. Fatty acids were extracted twice with 2 volumes of chloroform. The combined organic phases were dried, reconstituted in methanol, and subjected to reversed-phase HPLC.

Chemicals. We obtained histamine, serotonin, indomethacin, and phosphomolybdic acid from Sigma; arachidonic acid from Nu-CheckPrep (Elysian, MN); phospholipid standards from Avanti Polar Lipids (Birmingham, AL); 15-, 13-, 12-, 5-, 8-, 11-, and 9-HETE, eicosatetraynoic acid (ETYA), nordihydroguaiaretic acid, 5,6-methanoleukotriene $\mathrm{A}_{4}$ methyl ester, and 5,6-dehydroarachidonic acid from Biomol 
Table 2. Fatty acid composition of Aplysia neural phospholipids

\begin{tabular}{lrrr}
\multirow{4}{*}{$\begin{array}{l}\text { Fatty } \\
\text { acid }\end{array}$} & \multicolumn{3}{l}{ Relative abundance (area \%) } \\
\cline { 2 - 4 } & \multicolumn{1}{l}{ PE } & \multicolumn{1}{l}{ PC + PI } \\
\hline $14: 0$ & N.D. & $3.1 \pm 0.5$ & N.D. \\
$14: 1$ & $5.4 \pm 1.4$ & $1.4 \pm 1.2$ & $4.3 \pm 1.5$ \\
$16: 0$ & $2.8 \pm 0.9$ & $2.2 \pm 1.0$ & $1.5 \pm 0.6$ \\
$16: 1$ & $1.8 \pm 1.4$ & $2.1 \pm 1.4$ & N.D. \\
$18: 0$ & $4.3 \pm 0.7$ & $5.4 \pm 2.6$ & $19.0 \pm 4.8$ \\
$18: 1$ & $2.0 \pm 1.3$ & $8.6 \pm 3.3$ & $3.2 \pm 1.7$ \\
$18: 2$ & $2.7 \pm 0.9$ & $4.1 \pm 1.7$ & $2.3 \pm 1.1$ \\
$20: 1$ & $2.2 \pm 0.1$ & $2.8 \pm 1.3$ & $3.3 \pm 1.2$ \\
$20: 4$ & $7.5 \pm 2.5$ & $8.3 \pm 3.8$ & $6.9 \pm 4.9$ \\
$20: 5$ & $2.3 \pm 0.8$ & $4.7 \pm 1.0$ & $3.6 \pm 1.1$ \\
$22: 2$ & $4.3 \pm 1.2$ & $1.8 \pm 0.9$ & $4.9 \pm 1.5$ \\
$22: 4$ & $24.7 \pm 6.8$ & $11.8 \pm 4.0$ & $5.9 \pm 2.4$ \\
$22: 6$ & $4.5+1.4$ & $4.9+1.2$ & $3.9 \pm 2.1$ \\
$24: 0$ & $1.2 \pm 0.6$ & $0.8 \pm 0.2$ & N.D. \\
Others & $31.0 \pm 6.4$ & $37.6 \pm 8.3$ & $35.3 \pm 1.2$ \\
\hline
\end{tabular}

The phospholipids (phosphatidyl-ethanolamine, PE; -choline, PC; -serine and -inositol, PS and PI) were purified by TLC before the constituent fatty acids were transmethylated and analyzed by GC $(n-4)$. N.D., not detected (less than $0.4 \%$ area). Phospholipid classes were identified in preliminary experiments by labeling with both ${ }^{32} \mathrm{P}_{\mathrm{i}}$ and ${ }^{3} \mathrm{H}$-polar head precursors (Materials and Methods): PE constitutes $43.7 \pm 2.2 \%$ of the total phospholipids; PC, $34.6 \pm 2.8 \%$; PS + PI, $17.0 \pm 2.1 \%$ $(n=4)$. The occurrence of the phosphoglycerides in the plasmalogen form, frequent in mollusks (Roots and Johnston, 1965), was not investigated.

Research Laboratories (Philadelphia, PA), cimetidine from Smith, Kline \& French (Philadelphia, PA); HPLC and TLC solvents from Burdick \& Jackson (Muskegon, MI); and boron trifluoride from Kodak (Rochester, NY).

\section{Results}

Arachidonic acid is a constituent of Aplysia neural lipids

Arachidonic acid accounted for about $10 \%$ of the total fatty acids of Aplysia neural lipids, as determined by quantitative GC analysis (Table 1). Comparable proportions of arachidonic acid were measured in each isolated phospholipid class (Table 2). In addition, ${ }^{3} \mathrm{H}$-arachidonic acid was readily incorporated into the lipids of isolated neural components (Table 3). Neural components were used for these experiments because, with intact ganglia, most of the ${ }^{3} \mathrm{H}$-arachidonic acid was preferentially incorporated into the connective tissue sheath and did not reach the neurons. The presence of polyunsaturated fatty acids has been demonstrated in other mollusks (Voogt, 1972; Isay and Burasova, 1984). Komai et al. (1973), however, found no arachidonic acid or any other polyunsaturated fatty acid in the nervous tissue of Aplysia kurodai. As was suggested by these authors, this discrepancy most probably resulted from autooxidative degradation of these relatively unstable compounds.

\section{Arachidonic acid metabolites are produced in Aplysia nervous} tissue

To explore the physiological relevance of the eicosanoids in the nervous system of Aplysia, it was first essential to characterize the major metabolic pathways of arachidonic acid and to show that they are present in neurons. We found that both lipoxygenase and cyclo-oxygenase products of arachidonic acid could be formed by Aplysia neural components.

Identification of lipoxygenase products. ${ }^{3} \mathrm{H}$-arachidonic acid added to neural components was converted to labeled metabolites with the chromatographic properties of 12-HETE and

\begin{tabular}{lc}
\hline $\begin{array}{l}\text { Table 3. Incorporation of }{ }^{3} \mathbf{H} \text {-arachidonic acid into } \text { Aplysia neural } \\
\text { lipids }\end{array}$ & $\begin{array}{l}\text { Radioactivity } \\
(\% \text { of total on } \\
\text { chromatogram })\end{array}$ \\
& \\
& \\
\hline A. Total lipids & $55.5 \pm 3.4$ \\
Phospholipids & $13.5 \pm 3.1$ \\
Diacylglycerol & $0.9 \pm 0.7$ \\
Free fatty acids & $23.3 \pm 0.9$ \\
Triacylglycerol & $6.5 \pm 2.5$ \\
Cholesteryl esters & \\
B. Phospholipid classes & $15.8 \pm 1.9$ \\
PE & $36.3 \pm 3.2$ \\
PC & $40.0 \pm 4.1$ \\
PS + PI &
\end{tabular}

Lipid extracts from neural components labeled overnight with ${ }^{3} \mathrm{H}$-arachidonic acid were fractionated by TLC using solvent system $A$ (total lipids) or B (phospholipid classes) $(n=4)$. Total radioactivity on the TLC plate was, on average, 70,000 cpm (A) and 40,000 cpm (B). A similar distribution was obtained in 4 other determinations after labeling for 2 hr with ${ }^{3} \mathrm{H}$-arachidonic acid.

5-HETE, stable end products of arachidonic acid metabolism formed through the 12- and 5-lipoxygenase pathways. Separation of these products by HPLC system $I$ is shown in Figure $2 A$. In 12 similar experiments, $0.5 \mu \mathrm{Ci}$ of ${ }^{3} \mathrm{H}$-arachidonic acid were added to $0.1 \mathrm{ml}$ of artificial seawater containing on average about $8 \mathrm{mg}$ wet weight of tissue: $4925 \pm 108 \mathrm{cpm}$ were recovered after reversed-phase HPLC purification at the retention time of 12-HETE, and $3713 \pm 76 \mathrm{cpm}$ at the retention time of 5-HETE. Background radioactivity in the fractions around these peaks was $98 \pm 8 \mathrm{cpm}$.

The identity of 12-HETE was confirmed using several methods. In 2 experiments in which the radioactive material eluting with 12-HETE on reversed-phase HPLC was subjected to methylation and analyzed by normal-phase HPLC, the labeled product comigrated with 12-HETE methyl ester (Fig. 2B). Also, radioimmunoassay after isolation by reversed-phase HPLC revealed a single immunoreactive component at the retention time expected for 12-HETE (Fig. $2 A$, shaded area) $(n=2)$. Further structural analysis of this material was performed by UV spectrometry and GC/MS. For this purpose, the ganglia from the nervous systems of 100 Aplysia were homogenized and incubated for $30 \mathrm{~min}$ with arachidonic acid $(50 \mu \mathrm{M})$; 12-HETE was purified from an ether extract by normal-phase HPLC. Ultraviolet absorbance was monitored continuously at $235 \mathrm{~nm}\left(\mathrm{~A}_{235}\right)$, and full spectra were taken using a photodiode array detector. The HPLC chromatogram (Fig. $3 A$ ) shows a major peak of absorbance at $4.8 \mathrm{~min}$, the retention time of authentic 12-HETE. The spectrum of this product, shown in Figure $3 B$, is identical to that of authentic 12-HETE $\left(\lambda_{\max }, 235 \mathrm{~nm}\right) . \mathrm{GC} / \mathrm{MS}$ analysis of the purified product was carried out both in the negative ion chemical ionization (NICI) mode (using the pentafluorobenzyl ester, trimethylsilyl ether derivative, PFB-TMS) and in the positive ion electron impact (EI) mode (using the methyl ester trimethylsilyl ether derivative, Me-TMS) (Fig. 4).

The NICI spectrum of synthetic 12-HETE-PFB-TMS contains only one prominent ion, which is at $\mathrm{m} / \mathrm{z} 391$ (M-181). Consequently, we monitored the $\mathrm{M}-181$ ion for a samplc of the material from the neural incubate and observed a peak at the retention time expected for 12-HETE-PFB-TMS. We estimated that, by comparison with external standards, about $200 \mathrm{ng}$ of 
12-HETE had been injected. (Thus the total amount of 12HETE recovered from the nervous systems of 100 animals in this experiment would be $1 \mu \mathrm{g}$.) Analysis by EI mass spectrometry further confirmed the identification (Fig. $4 B$ ). Three characteristic ion fragments [m/z 391 (M-15), 295 (M-111), and 73] were chosen from the spectrum of synthetic 12-HETE-Me-TMS. These fragments we found to coelute from the GC at an equivalent chain length value identical to that of 12-HETE-Me-TMS.

Evidence that the second labeled metabolite is 5-HETE was provided only by normal-phase HPLC and by radioimmunoassay. The 2-step chromatographic procedure used to characterize 12-HETE was not practical for 5-HETE. In 3 control experiments, after the second reversed-phase HPLC step less than $10 \%$ of standard ${ }^{3} \mathrm{H}-5$-HETE was recovered. (In contrast, the recovery of ${ }^{3} \mathrm{H}-12$-HETE under the same conditions was 40-60\%.) Therefore, the labeled metabolites were extracted directly from bath samples and analyzed by normal-phase HPLC either as free fatty acids or after methylation with diazomethane. In both analyses, major radioactive components were found to elute with standards of 5-HETE or 5-HETE-Me (not shown). Similarly, radioimmunoassay was performed on the fractions collected from the reversed-phase HPLC separation (using system I; see Materials and Methods). Although the neural components released $100 \mathrm{pg} /$ ganglion of immunoreactive 5-HETE with the same retention time of the 5-HETE standard (19.5 min), this accounted for only $13 \%$ of total immunoreactive 5-HETE recovered. Most of the fractions yielded background values in the range of 11-26 pg/ganglion of immunoreactive material. In addition, 3 components, eluting at $7.5,10.5$, and $24 \mathrm{~min}$, contained 50,50 , and $58 \mathrm{pg} /$ ganglion of immunoreactivity. Detection of these additional components may be due to cross-reactivity of the antibody with other arachidonic acid metabolites, or with metabolites of different polyunsaturated fatty acids that are present in Aplysia (Tables 1 and 2). Because of the poor recovery, the identification of 5-HETE must be tentative.

The formation of 12-HETE and 5-HETE that we have shown suggests that 12- and 5-lipoxygenases are present in Aplysia neural components. The presence of these enzymes is further indicated by the following experiments. Neither metabolite was formed by neural components that had been boiled for $5 \mathrm{~min}$. Agents that block mammalian lipoxygenases inhibit the production of these metabolites in Aplysia. Nordihydroguaiaretic acid (NDGA) and ETYA inhibited the formation of ${ }^{3} \mathrm{H}-12$ HETE and ${ }^{3} \mathrm{H}-5$-HETE by neural components incubated with ${ }^{3} \mathrm{H}$-arachidonic acid $(0.5 \mu \mathrm{Ci} / 0.1 \mathrm{ml}$ for $10 \mathrm{~min})$ (Table 4). Halfmaximal inhibition of ${ }^{3} \mathrm{H}-12$-HETE formation was obtained with $15 \mu \mathrm{M}$ ETYA, and of ${ }^{3} \mathrm{H}-5$-HETE with $0.5 \mu \mathrm{M}$ ETYA. NDGA blocked the generation of both hydroxy acids with equal effectiveness $\left(\mathrm{IC}_{50}, 3 \mu \mathrm{M}\right)$. Two specific inhibitors of mammalian 5-lipoxygenase, 5,6-methanoleukotriene $A_{4}$ methyl ester $\left(\mathrm{MLTA}_{4}\right)$ and 5,6-dehydroarachidonic acid (DHA), were also tested. Aplysia 5 -lipoxygenase activity was inhibited by DHA with an $\mathrm{IC}_{50}$ of $10 \mu \mathrm{M}$. Inhibition of ${ }^{3} \mathrm{H}-5$-HETE release by $50 \%$ was obtained with $5 \mu \mathrm{M} \mathrm{MLTA}_{4}$. The tentative biochemical identification of 5-HETE is strengthened by these pharmacological results with mammalian 5-lipoxygenase blockers.

Fate of ${ }^{3} \mathrm{H}-12-H E T E$ and ${ }^{3} \mathrm{H}-5-H E T E$. We found that the primary metabolic fate of the hydroxy acids in Aplysia nervous tissue is esterification to glycerophospholipids and neutral lipids, as in mammalian retina (Birkle and Bazan, 1984). When ${ }^{3} \mathrm{H}-12$-HETE was incubated for 10 min with Aplysia ganglia,

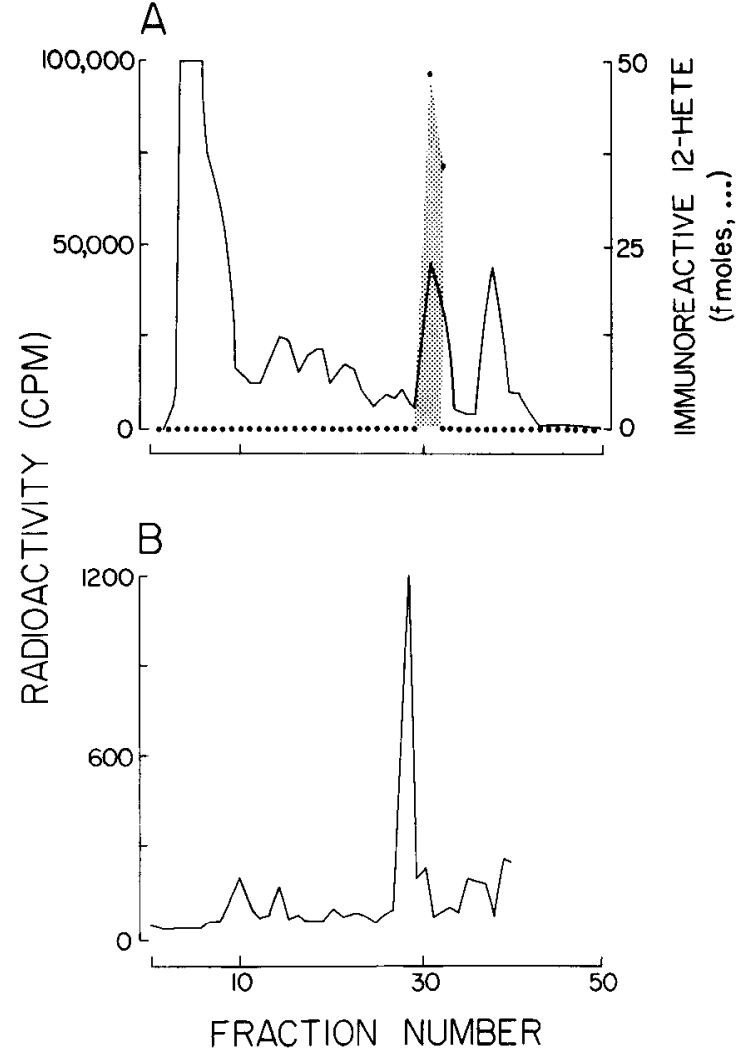

Figure 2. Identification of 12-HETE formed by Aplysia neural components. $A$, Reversed-phase HPLC and immunochromatography. Bath samples from neural components, incubated with ${ }^{3} \mathrm{H}$-arachidonic acid $(0.5 \mu \mathrm{Ci}$ in $0.1 \mathrm{ml}$ for $30 \mathrm{~min})$, were subjected to reversed-phase HPLC (solvent system I); each $30 \mathrm{sec}$ fraction was counted by liquid scintillation; the solid line (cpm) was drawn by connecting each point. The 2 major components that are separated from the solvent front eluted at the retention times of 12-HETE and 5-HETE. The material at the solvent front represents unidentified polar metabolites of arachidonic acid. The amounts of radioactivity on the chromatogram correspond to the production of the neural components from the cerebral, paired pleuropedal and abdominal ganglion of one specimen. In another experiment, bath samples from neural components incubated with arachidonic acid $(15 \mu \mathrm{M})$ were fractionated by HPLC and the material eluting at the retention time of 12-HETE was chromatographed again on the same HPLC system. After the second HPLC step, the eluted fractions were dried, reconstituted in phosphate buffer, and analyzed by radioimmunoassay, using commercial antibody against 12-HETE. The immunoreactive material, indicated by the shaded area, had the same retention time as did the 12-HETE standard. Recovery of standard ${ }^{3} \mathrm{H}-12$-HETE after 2 chromatographic steps was typically $40-60 \%(n=3)$. $B$, Normalphase HPLC. The radioactive material eluting with 12-HETE on reversed-phase HPLC was collected, dried, subjected to methylation, and chromatographed by normal-phase HPLC. The major radioactive component was eluted at the retention time of 12-HETE methyl ester. Recovery was only $10-20 \%$.

$24.5 \%$ of the label was incorporated into lipid $(n=4)$; the radioactivity was found to be equally distributed between phospholipid and neutral lipids: phosphatidyl-ethanolamine, $11.6 \pm$ $3.2 \%$; -choline, $28.8 \pm 4.1 \%$; -serine and -inositol, $9.3 \pm 2.9 \%$. To determine whether the label represented esterified 12-HETE or a metabolite, the lipid extract was saponified and the hydroxy acids examined by reversed-phase HPLC. The distribution of radioactivity on the chromatogram was identical to that of control experiments in which authentic ${ }^{3} \mathrm{H}-12$-HETE had been subjected to hydrolysis, extraction, and purification by HPLC (data not shown). In 4 similar experiments on the fate of ${ }^{3} \mathrm{H}-5$-HETE, 

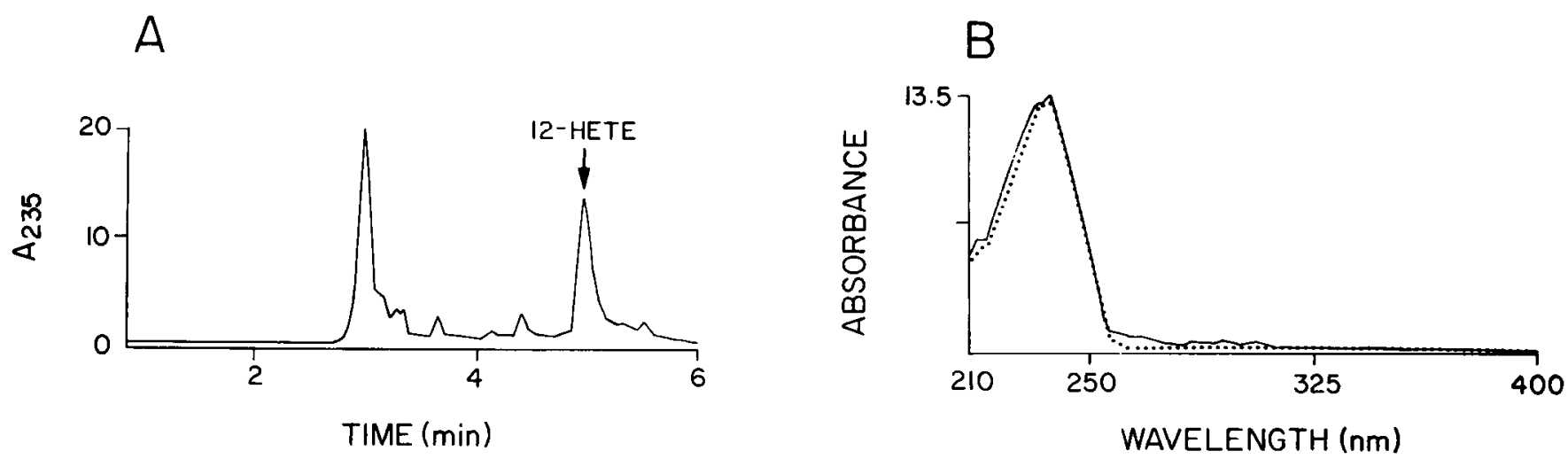

Figure 3. Identification of 12-HETE formed by Aplysia neural tissue analysis by UV spectrometry. The homogenate of neural ganglia from 100 animals was incubated with arachidonic acid $(50 \mu \mathrm{M})$ for $30 \mathrm{~min}$, and the lipid cxtract was subjected to normal-phase HPLC purification (see Materials and Methods). $A, \mathrm{~A}_{235}$ absorbance was monitored continuously. A major peak was observed at the retention time of the 12-HETE standard (4.8 min, indicated by the arrow). B, The full spectrum of this material (continuous line) was identical to that of authentic 12-HETE (dotted line).

which was also incorporated into tissue lipids, we found $30 \%$ in phospholipids (phosphatidyl-ethanolamine, $11.6 \pm 3.2 \%$; -choline, $11.0 \pm 2.1 \%$; -serine and -inositol, $4.8 \pm 1.9 \%$; ; and the rest in neutral lipids. No polar metabolites were found in bath samples of ganglia incubated with ${ }^{3} \mathrm{H}-12$-HETE or ${ }^{3} \mathrm{H}-5$ HETE analyzed by reversed-phase HPLC ( $n=2$; not shown), indicating that in Aplysia, as in mammalian tissues (Stenson and Parker, 1979; Birkle and Bazan, 1984), these hydroxy acids are not rapidly metabolized.

Identification of cyclo-oxygenase products. Levine and Kobayashi (1983) previously found immunoreactive $\mathrm{PGE}_{2}$ and $\mathrm{PGF}_{2 \alpha}$ in unextracted aqueous homogenates of Aplysia ganglia. They did not purify the products before immunological analysis, however. Christ and Van Dorp (1972) reported the production of prostaglandins in non-neural tissues of other invertebrates. We investigated the formation of prostaglandins using neural components labeled overnight with ${ }^{3} \mathrm{H}$-arachidonic acid (Materials and Methods). A major radioactive substance with HPLC characteristics identical to those of $\mathrm{PGE}_{2}$ was released into the bath from neural components during a $30 \mathrm{~min}$ incubation (Fig. 5). Minor labeled components were also released, with retention times of $\mathrm{PGF}_{2 \alpha}$ and of 6-keto-PGF ${ }_{1 \alpha}$, the stable hydrolysis product of prostacyclin. Six similar experiments identifying these prostanoids were performed. The radioactive material eluting with the solvent front (Fig. 5) has not yet been identified. [It is likely to include, however, more polar metabolites of arachidonic acid such as dihydroxy, epoxy-hydroxy, and trihydroxy derivatives that have been described in other systems (Bryant and Bailey, 1979; Pace-Asciak et al., 1983; German and Kinsella, 1986). These metabolites are currently being studied in our laboratory (Piomelli et al., 1987a).]

The identities of $\mathrm{PGE}_{2}$ and $\mathrm{PGF}_{2 \alpha}$ were confirmed by radioimmunoassay after purification by reversed-phase HPIC. The bath contained a single component of $\mathrm{PGE}_{2}$-like immunoreactivity, which eluted from the reversed-phase HPLC at the retention time expected for this substance (Fig. 5). Similarly, immunoreactive $\mathrm{PGF}_{2 \alpha}(0.72 \mathrm{pmol})$ was detected at the retention characteristic of this compound ( $n=2$; data not shown). Some material that reacted with the $\mathrm{PGF}_{2 \alpha}$ antibody was also found in fractions with the retention time of $\mathrm{PGE}_{2}$. This immunoreactivity may be due to cross-reactivity of the antibody used with $\mathrm{PGE}_{2}(0.3 \%$ according to information provided by Seragen). Alternatively, it may result from cross-reactivity with cyclo-oxygenase products derived from polyunsaturated fatty acids other than arachidonic acid (Levine and Kobayashi, 1983). No immunoreactive 6-keto- $\mathrm{PGF}_{1 \alpha}$ was detected in HPLC fractions obtained from similiar experiments $(n=2$; lower limit of detection, $75 \mathrm{pg} / 0.1 \mathrm{ml}$ ).

The formation of $\mathrm{PGE}_{2}$ and $\mathrm{PGF}_{2 \alpha}$ suggests that cyclo-oxygenase activity is present in Aplysia nervous tissue. This is fur-

Table 4. Effects of various lipoxygenase inhibitors on formation of ${ }^{3} \mathrm{H}-12-\mathrm{HETE}$ and ${ }^{3} \mathrm{H}-5-\mathrm{HETE}$ by Aplysia neural tissue

\begin{tabular}{|c|c|c|c|c|c|c|}
\hline \multirow{2}{*}{$\frac{\text { Treatment }}{\text { Control }}$} & \multirow{2}{*}{$\begin{array}{l}\text { Concen- } \\
\text { tration } \\
(\mu \mathrm{M}) \\
-\end{array}$} & \multicolumn{2}{|c|}{$\begin{array}{c}{ }^{3} \mathrm{H}-12-\mathrm{HETE} \\
(\mathrm{cpm} / \text { ganglion })^{a}\end{array}$} & \multicolumn{3}{|c|}{$\begin{array}{l}{ }^{3} \mathrm{H}-12 \text {-HETE }{ }^{3} \mathrm{H}-5 \text {-HETE } \\
\text { (\% of control) }\end{array}$} \\
\hline & & $4295 \pm 1091$ & $3632 \pm 736$ & 100 & 100 & 12 \\
\hline ETYA & 30 & $71 \pm 17$ & $72 \pm 17$ & 1.6 & 1.9 & 4 \\
\hline NDGA & 30 & $70 \pm 15$ & $70 \pm 8$ & 1.6 & 1.9 & 3 \\
\hline DHA & 30 & $972 \pm 205$ & $41 \pm 7$ & 22.6 & 1.1 & 3 \\
\hline $\mathrm{MLTA}_{4}$ & 15 & $1835 \pm 15$ & $68 \pm 3$ & 42.7 & 1.8 & 5 \\
\hline
\end{tabular}

Neural tissue from Aplysia ganglia was incubated for $10 \mathrm{~min}$ in artificial seawater containing ${ }^{3} \mathrm{H}$-arachidonic acid $(0.5$ $\mu \mathrm{Ci} / 0.1 \mathrm{ml}$ ) with or without a lipoxygenase blocker in $n$ experiments. Labeled hydroxy acids were purified from bath samples by reversed-phase HPLC (solvent system I). ETYA, eicosatetraynoic acid; NDGA, nordihydroguaiaretic acid; DHA, 5,6-dehydroarachidonic acid; MLTA $_{4}, 5,6$-methanoleukotriene $A_{4}$ methyl ester.

${ }^{a}$ Means \pm SEM. 


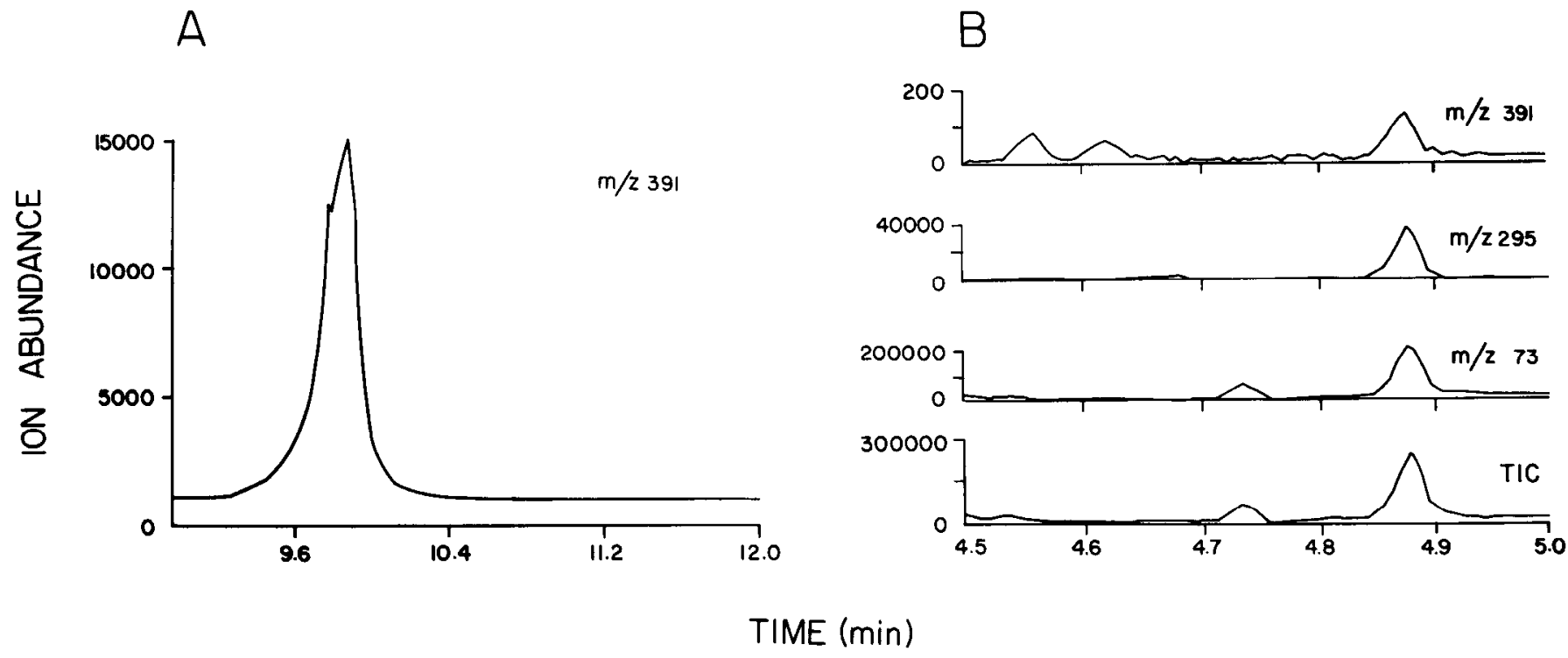

Figure 4. Identification of 12-HETE formed by Aplysia neural tissue: analysis by gas-chromatography/mass spectrometry. The lipid extract from the homogenate of nervous tissue incubated with arachidonic acid (see legend to Fig. 3) was fractionated by normal-phase HPLC. Material with the retention time of 12-HETE was collected and derivatized as described (see Materials and Mcthods). $A$, Analysis by ncgativc-ion chemical ionization. We monitored a diagnostic ion at $\mathrm{m} / \mathrm{z} 391$ produced by loss of PFB. The peak observed had the expected retention time for authentic 12-HETE-PFB-TMS. $B$, Analysis by electron-impact ionization. Characteristic ions for 12-HETE-Me-TMS (m/z 391, 295, and 73) were observed at the retention time expected for this compound. Total ion current $(T I C)$ is displayed in the lowest panel.

ther indicated since the cyclo-oxygenase blocker indomethacin inhibited the formation of these products with an $\mathrm{IC}_{50}$ of 0.5 $\mu \mathrm{M}$.

\section{Arachidonic acid metabolism in single nerve cell bodies and lerminals}

We have shown that neural components of Aplysia nervous tissue metabolize arachidonic acid. In order to provide evidence that lipoxygenase and cyclo-oxygenase activities actually occur in nerve cells, we have studied the metabolism of arachidonic acid in synaptosomes and isolated cell bodies.

Synaptosomes. Gentle mechanical stimulation of synaptosomes labeled by incubation with ${ }^{3} \mathrm{H}$-arachidonic acid resulted in the release of radioactive eicosanoids into the bath. No me-

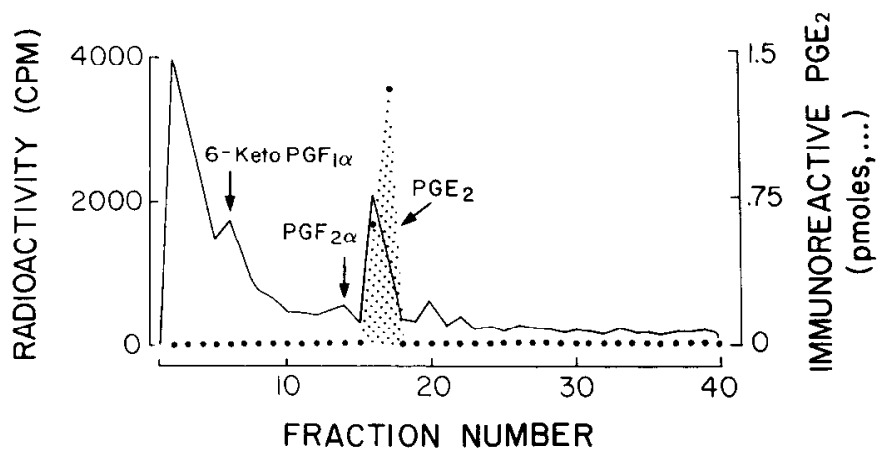

Figure 5. Identification of $\mathrm{PGE}_{2}$. Neural components from the ganglia of one animal were labeled overnight with ${ }^{3} \mathrm{H}$-arachidonic acid $(2.5 \mu \mathrm{Ci} /$ $\mathrm{ml}$ ). After washing out unincorporated label, we incubated the tissue for $30 \mathrm{~min}$. Bath samples were analyzed by reversed-phase HPLC (solvent system II); $30 \mathrm{sec}$ fractions were collected for counting. Arrows indicate the position of $\mathrm{PGE}_{2}, \mathrm{PGF}_{2 \alpha}$, and 6-keto-PGF $\mathrm{PG}_{1 \alpha}$ standards. Bath samples from an incubation of neural components with arachidonic acid (15 $\mu \mathrm{M})$ were fractionated by HPLC (system II); each fraction was dried and reconstituted in phosphate buffer. PGE $_{2}$ (dotted line) was identified by radioimmunoassay.

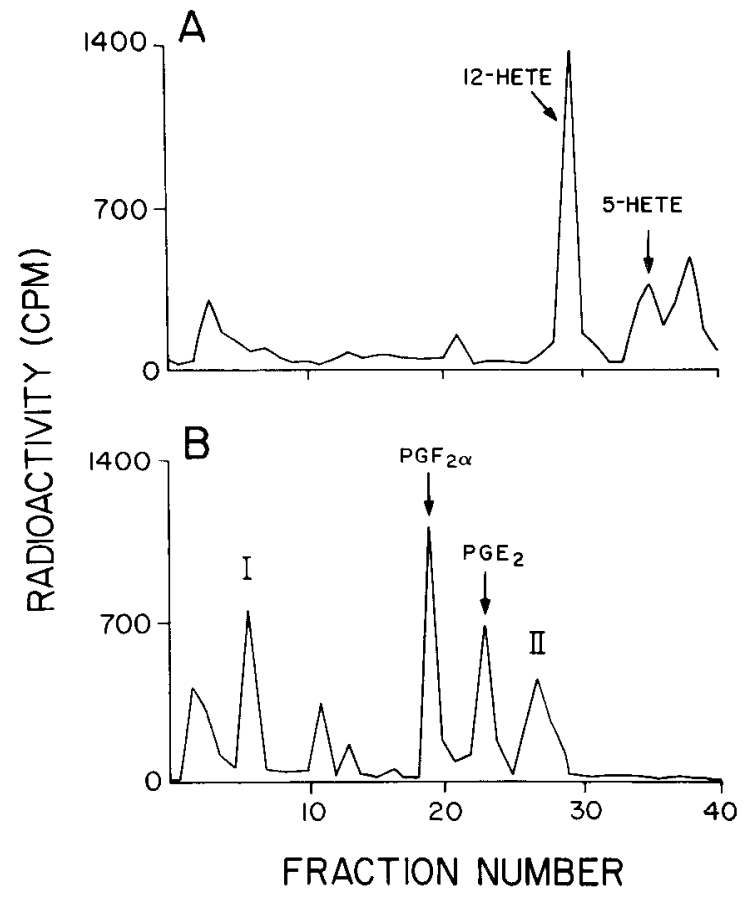

Figure 6. Arachidonic acid metabolism in Aplysia synaptosomes. Synaptosomes were labeled for $2 \mathrm{hr}$ with ${ }^{3} \mathrm{H}$-arachidonic acid $(25 \mu \mathrm{Ci} / \mathrm{ml})$ and stimulated to release eicosanoids by gentle agitation. After $1 \mathrm{~min}$, samples of the bath were subjected to reversed-phase HPLC; $30 \mathrm{sec}$ fractions were collected for counting. ${ }^{3} \mathrm{H}$-arachidonic acid was incorporated into the major phospholipid classes in the synaptosomes. Of the total label present after separation of the lipids on TLC in system $\mathrm{B}, 7.3 \%$ was incorporated in phosphatidyl-choline, $4.8 \%$ in phosphatidyl-ethanolamine, and $22 \%$ in phosphatidyl-serine and -inositol (average of 2 determinations). $A$, Formation of hydroxy acids (HPLC system I). The retention times of 12-IIETE and 5-IIETE are indicated. $B$, Formation of prostaglandins (HPLC solvent system II). ${ }^{3} \mathrm{H}-\mathrm{PGF}_{2 \mathrm{x}}$ and ${ }^{3} \mathrm{H}-\mathrm{PGE}_{2}$ were detected. Two labeled components, designated I and II, had the retention times of standard ${ }^{3} \mathrm{H}-6$-keto- $\mathrm{PGF}_{1 \alpha}$ and $\mathrm{PGD}_{2}$. 


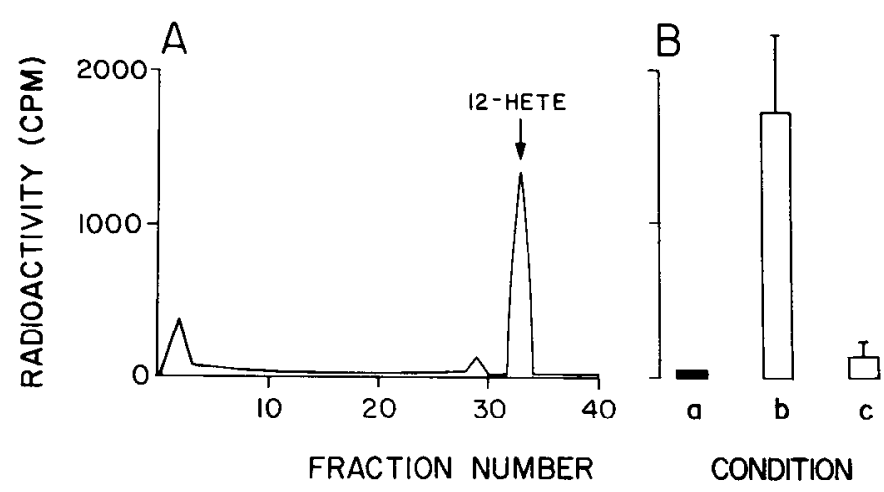

Figure 7. Stimulation of ${ }^{3} \mathrm{H}-12-\mathrm{HETE}$ formation by histamine. Neural components, labeled by incubation for $2 \mathrm{hr}$ with ${ }^{3} \mathrm{H}$-arachidonic acid $(25 \mu \mathrm{Ci} / \mathrm{ml}$ ), were exposed for $1 \mathrm{~min}$ to histamine $(50 \mu \mathrm{M})$. Samples were subjected to reversed-phase HPLC as in Figure 2, and fractions analyzed for radioactivity. $A$, Representative chromatogram, typical of 4 expcriments. The effect of histamine on the formation of $\mathrm{PGE}_{2}$ was also tested, but no difference from controls was observed $(n=3$; data not shown). $B,{ }^{3} \mathrm{H}-12$-HETE formation under different conditions. Control, $a(n=4)$; histamine $(50 \mu \mathrm{M}), b(n=4)$; histamine $(50 \mu \mathrm{M})$ together with cimetidine $(100 \mu \mathrm{M}), c(n=3)$.

tabolites were detected without stimulation during the $1 \mathrm{~min}$ incubation. ${ }^{3} \mathrm{H}$-12-HETE was the major hydroxy acid formed under these conditions; material eluting at the retention time of ${ }^{3} \mathrm{H}-5$-HETE and an unidentified radioactive component were also seen (Fig. $6 \mathrm{~A}$ ). ${ }^{3} \mathrm{H}$-prostaglandins $\mathrm{E}_{2}$ and $\mathrm{F}_{2 \alpha}$ were also found (Fig. 6B). In addition, labeled material was observed at the retention times of 6-keto- $\mathrm{PGF}_{1 \alpha}$ and $\mathrm{PGD}_{2}$ (Fig. $6 \mathrm{~B}$ ).

$R 2$ cell bodies. Gentle mechanical stimulation of single, isolated $\mathrm{R} 2$ cell bodies labeled with ${ }^{3} \mathrm{H}$-arachidonic acid resulted in the release of radioactive hydroxy acids and prostaglandins. ${ }^{3} \mathrm{H}-12$-HETE accounted for $6.7 \pm 1.5 \%$ and ${ }^{3} \mathrm{H}-5$-HETE, $8.3 \pm$ $2.1 \%$ of the total radioactivity recovered $(13,592 \pm 4693 \mathrm{cpm}$; $n=4$ ) after reversed-phase HPLC. In 2 experiments, ${ }^{3} \mathrm{H}-\mathrm{PGE}_{2}$ accounted for 3.8 and $4.0 \%$ and ${ }^{3} \mathrm{H}-\mathrm{PGF}_{2 \alpha}$ for 3.9 and $5.7 \%$ of an average of 10,000 total counts per minute. In preliminary experiments, we found that the hydroxy acids are also formed by isolated cell bodies of other identified neurons (pleural sensory cells, bag cells, and L7).

\section{Stimulation of ${ }^{3} \mathrm{H}-\mathrm{HETE}$ formation by histamine}

Histamine (McCaman and Weinreich, 1985; Kretz et al., 1986b) and serotonin (Kupfermann, 1979) are the modulatory transmitters most thoroughly characterized in Aplysia. In vertebrates, both substances stimulate the release of arachidonic acid from lung (Blackwell et al., 1978) and vascular smooth muscle and endothelial cells (Baenziger et al., 1980; Coughlin et al., 1984). We therefore approached the possibility that metabolites of arachidonic acid are produced from endogenous lipids as a consequence of receptor activation by testing whether a 1 min application of histamine or serotonin releases eicosanoids from ganglia previously labeled with ${ }^{3} \mathrm{H}$-arachidonic acid. Histamine caused the production of ${ }^{3} \mathrm{H}-12$-HETE $(1710 \pm 358 \mathrm{cpm} ; n=$ 4) (Fig. 7). Under these conditions, no ${ }^{3} \mathrm{H}-5-\mathrm{HETE}$ or prostaglandins were detected. Cimetidine blocks certain types of histaminergic responses in Aplysia, particularly slow IPSPs (Gruol and Weinreich, 1979; Kretz et al., 1986b). Addition of cimetidine $\left(10^{-4} \mathrm{M}\right)$ greatly reduced the histamine-evoked release of ${ }^{3} \mathrm{H}-12$-HETE (Fig. $7 B$ ). Application of serotonin $(100 \mu \mathrm{M} ; n=$

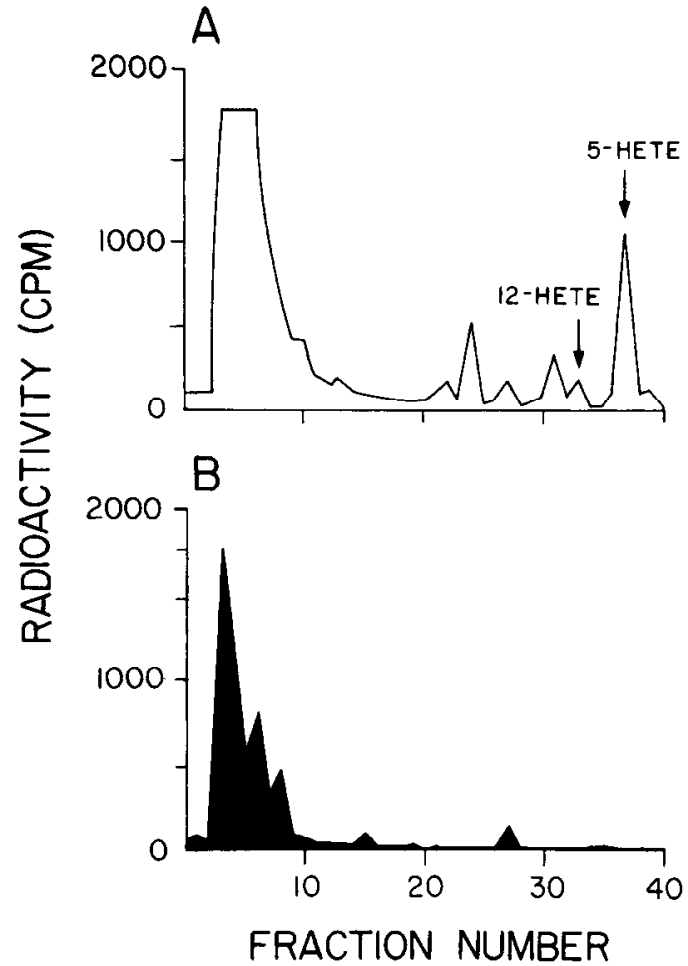

Figure 8. HETE formation intracellular stimulation of $\mathrm{C} 2$ neurons. Cerebral ganglia were labeled overnight with ${ }^{3} \mathrm{H}$-arachidonic acid $(25$ $\mu \mathrm{Ci} / \mathrm{ml}$ ). Samples from the bath were analyzed by reversed-phase HPLC as in Figure 2. $A$, Relcasc of ${ }^{3} \mathrm{H}$-hydroxy acids after stimulation of $\mathrm{C} 2$ (see Fig. $1, A, B$ ). $B$, From the same ganglion before stimulation. The retention times of 12-HETE and 5-HETE are indicated. The peak just to the left of 12-HETE had the retention time of 15-HETE, but appeared in only 2 of the 9 experiments.

3) or of vehicle alone (artificial seawater; $n=7$ ) was without effect.

Depolarization produced by increasing the concentration of extracellular $\mathrm{K}^{+}$to $100 \mathrm{~mm}$ (substituted for $\mathrm{Na}^{+} ; n=3$ ) only weakly stimulated release of ${ }^{3} \mathrm{H}-12$-HETE $(151 \pm 42 \mathrm{cpm})$ and of material eluting as ${ }^{3} \mathrm{H}-5$-HETE $(116 \pm 20 \mathrm{cpm})$, indicating that formation of the hydroxy acids is promoted by activation of specific receptors.

Intracellular stimulation of specific neurons causes release of lipoxygenase and cyclo-oxygenase products

We next tested whether endogenous transmitter released by stimulating individual identified histaminergic or serotonergic neurons might also activate arachidonic acid metabolism.

C2 neurons. C2 is a multiaction neuron in the cerebral ganglion of Aplysia and is a well-characterized histaminergic neuron (Weinreich et al., 1975; McCaman and McKenna, 1978; McCaman and Weinreich, 1982, 1985; Schwartz et al., 1986). Both histamine (Hintzen and Riehl, 1985) and stimulation of $\mathrm{C} 2$ have been shown to mediate presynaptic inhibition at specific synapses in the cerebral ganglion (Chiel et al., 1983). We stimulated C2 in ganglia labeled with ${ }^{3} \mathrm{H}$-arachidonic acid and analyzed the bath for ${ }^{3} \mathrm{H}$-hydroxy acids. Stimulation of $\mathrm{C} 2$ at physiological rates evoked the release of radioactive hydroxy acids. The major product was ${ }^{3} \mathrm{H}-5$-HETE $(1274 \pm 733 \mathrm{cpm} /$ ganglion; $n=5$ ); only a small amount of 12 -HETE was detected (146 $\pm 28 \mathrm{cpm} /$ ganglion). A typical separation by reversed- 


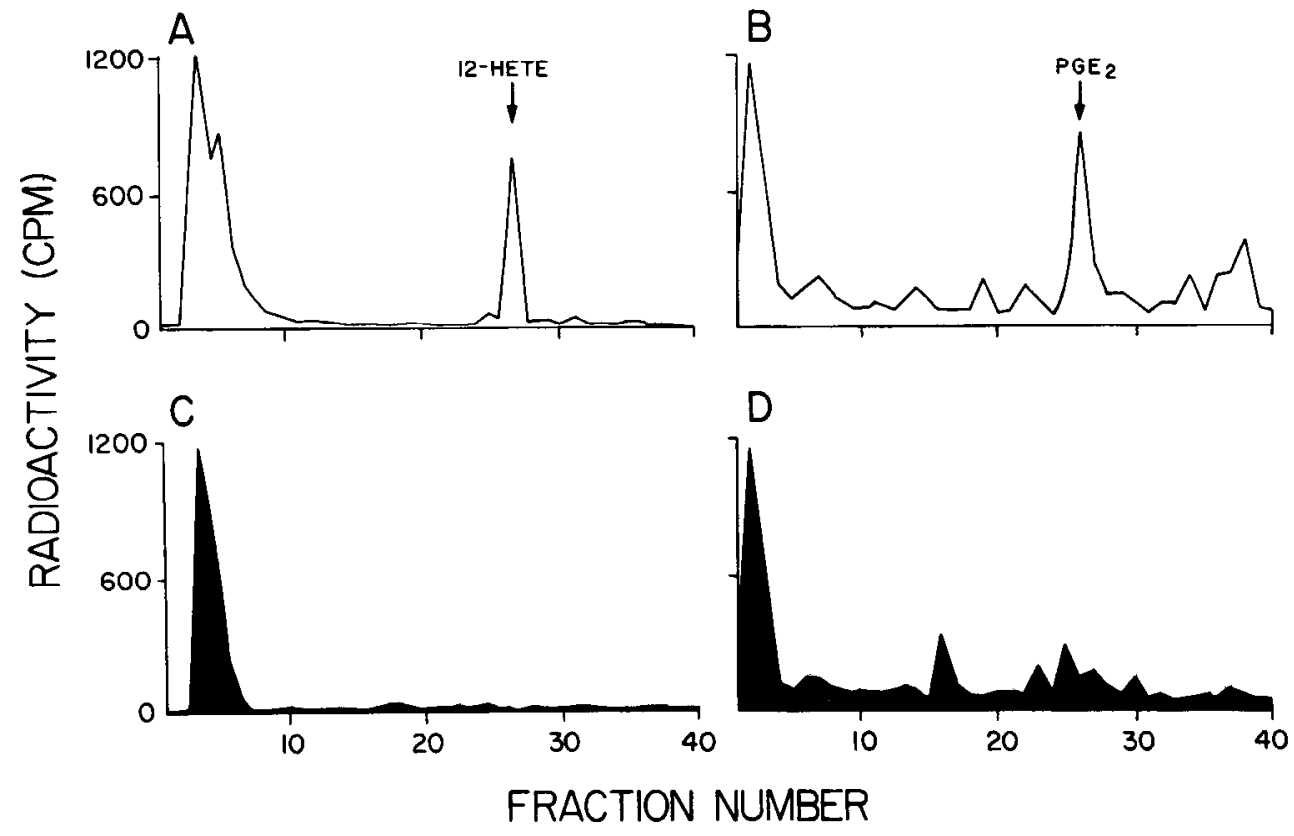

Figure 9. Formation of 12-HETE and $\mathrm{PGE}_{2}$ produced by intracellular stimulation of $\mathrm{L} 32$ neurons. Labeled abdominal ganglia were stimulated as described in the legend to Figure $1 B$. HPLC chromatograms of bath samples taken before $(C, D)$ and after $(A, B)$ stimulation. Stimulation of L32 evoked production of labeled 12-HETE and $\mathrm{PGE}_{2}$. Samples were analyzed by reversed-phase HPLC for 12-HETE, as described for Figure 2, and for $\mathrm{PGE}_{2}$, as described for Figure 3. phase HPLC is shown in Figure 8. The predominance of 5-HETE evoked by firing $\mathrm{C} 2$ is markedly different from the pattern of hydroxy acid synthesis obtained after application of histamine (Fig. 7) or after stimulation of another identified neuron, L32 (Fig. 9). Interestingly, the amount of polar material appearing at the solvent front was also increased by stimulating C2 (Fig. 8). Although this material has not yet been analyzed, it is likely to contain prostaglandins and other, more polar, derivatives of arachidonic acid.

The minimal stimulation protocol tested ( 20 spikes/ $1 \mathrm{sec}$ ) was sufficient to cause production of the labeled hydroxy acids. Control samples were taken both before stimulation and after each bath wash. No counts above background were detected at the retention times of the hydroxy acids in samples from the same ganglia that had been used to examine the action of $\mathrm{C} 2(n=3)$. To rule out the possibility that cell depolarization contributes to eicosanoid release, we also stimulated intracellularly the serotonergic cell GCN; no detectable metabolites were found. [In Aplysia, no synaptic connections of GCN are known to occur within the cerebral ganglion (see Granzow and Fraser Rowell, 1981); postsynaptic targets are therefore absent in these experiments. Thus we cannot exclude the possibility that stimulation of GCN might result in the release of eicosanoids from its follower cells.] In 2 experiments, C2 was again stimulated in the same ganglion, and ${ }^{3} \mathrm{H}$-hydroxy acids were produced, indicating that the failure with GCN did not result from depleting the labeled precursor. Cimetidine $\left(10^{-4} \mathrm{M}\right)$ blocked the release of HETE produced by stimulating $\mathrm{C} 2(n=3)$. In 2 experiments, the effect of cimetidine was found to be reversible after the drug was washed out. These experiments suggest that the histamine released by stimulating $\mathrm{C} 2$ ncurons promotes the formation of lipoxygenase products through cimetidine-sensitive receptors.

L32 neurons. The L32 cells, a group of putative histaminergic interneurons in the abdominal ganglion, make slow inhibitory connections on L10 and most left-upper-quadrant neurons, and a dual-action fast-excitatory/slow-inhibitory connection on L14. Presynaptic inhibition of L10 is produced by the L32-L10 IPSP (Byrne, 1980a; Kretz et al., 1986a). Intracellular stimulation of
$\mathrm{I} 32$ neurons in ganglia labeled with ${ }^{3} \mathrm{H}$-arachidonic acid induced the release of ${ }^{3} \mathrm{H}-12$-HETE (Fig. 9). Stimulation of L32, unlike that of $\mathrm{C} 2$, did not promote formation of material eluting as 5-HETE. In 5 separate experiments, the ${ }^{3} \mathrm{H}-12$-HETE fraction contained $450 \pm 85 \mathrm{cpm} /$ ganglion after stimulation of L32. No counts above background were detected in the fractions containing 12-HETE and 5-HETE without stimulation.

We also examined the production of prostaglandins. In 2 experiments, intracellular stimulation resulted in the appearance of 377 and $619 \mathrm{cpm}$ of ${ }^{3} \mathrm{H}-\mathrm{PGE}_{2}$, with only background values in unstimulated controls.

\section{Discussion}

Metabolism of arachidonic acid in Aplysia neurons

Arachidonic acid is present in substantial amounts in nervous tissue of Aplysia, mainly esterified in glycerophospholipids, and, when released, can be metabolized through both lipoxygenase and cyclo-oxygenase pathways (Figs. 2-6). Using HPLC, radioimmunoassay, and GC/MS, we identified the 12-lipoxygenase product, 12-HETE. A second arachidonic acid metabolite was identified tentatively as 5-HETE on the basis of its chromatographic behavior and immunoreactivity, and because its formation was blocked by 5-lipoxygenase inhibitors. We found that both of these hydroxy acids can be incorporated into cell lipids as in mammalian tissue (Stenson and Parker, 1979; Birkle and Bazan, 1984). Best characterized in platelets, neutrophils, and other blood cells (Needleman et al., 1986), the distribution of 12-lipoxygenase is widespread; 12-lipoxygenase is present in mammalian brain (Adesuyi et al., 1985) and neuroblastoma cells (Birkle and Ellis, 1983). 5-Lipoxygenase, which is characteristic of inflammatory cells, is also found in the mammalian central nervous system (Lindgren et al., 1984; Adesuyi et al., 1985; Shimizu et al., 1987). The prostaglandins $P \mathrm{CE}_{2}$ and $\mathrm{PGF}_{2 u}$ were prominent products of the cyclo-oxygenase pathway, but other prostanoids are also likely to be formed (Figs. 6, 7). These cyclo-oxygenase products are present in virtually all vertebrate tissues, including the brain (Wolfe, 1982).

Even though some glial cells remain associated with the cell 
membrane of isolated nerve cell bodies (Giller and Schwartz, 1971), our experiments with isolated R2 somata suggest that it is likely that both lipoxygenase and cyclo-oxygenase pathways function within neurons: non-neural elements (connective tissue, muscle, blood vessels, and blood cells) are absent. The presence of multiple pathways of arachidonic acid metabolism in neurons, each with several identified intermediates and possibly many as-yet unidentified ones, may make the task of assigning function difficult, but it offers a rich variety of candidates for participation in neuronal action.

In Aplysia, as in mammals, hydroxy acids and prostaglandins can rapidly pass through cell membranes to appear in the bath. We do not know whether the stable metabolites that were recovered extracellularly present a distorted picture of the products actually formed. Answering this question requires analysis of metabolites within the neuron, which we have not yet attempted to do.

\section{Receptor mediation}

Birkle and Bazan (1984) have shown that membrane depolarization causes arachidonate turnover and formation of 12-HETE in rat brain. Depolarizing Aplysia neuronal membranes in the cerebral ganglion or in synaptosomes by increasing the concentration of extracellular $\mathrm{K}^{+}$ion only marginally stimulated the formation of hydroxy acids. While depolarization at some sites may be effective, experiments in which histamine was applied to neural components suggest that the stimulation of arachidonic acid metabolism observed is receptor-mediated, and the promotion of the metabolism by firing $\mathrm{C} 2$, an identified histaminergic neuron, provides strong support for this idea. Not all histamine receptors appear to stimulate turnover of arachidonic acid, however. Cimetidine in Aplysia selectively blocks hyperpolarizing responses to histamine, but not responses that are depolarizing (like the one produced on GCN; Gruol and Weinreich, 1979). We found that cimetidine blocks the turnover evoked by stimulating $\mathrm{C} 2$. This suggests that release of arachidonic acid is mediated by histamine receptors responsible for some forms of inhibition, and not by receptors with excitatory effects. Not all modulatory transmitters stimulate the formation of hydroxy acids from arachidonic acid: application of serotonin was without effect.

Intracellular stimulation of L32 neurons, a cluster of identified cells that mediate presynaptic inhibition in the abdominal ganglion, also promotes the formation of 12-HETE and $\mathrm{PGE}_{2}$. Although there is some evidence that L32 cells are also histaminergic, this has not been established definitively (Kretz et al., 1986a, b).

We suggest that receptors for histamine are coupled to an effector phospholipase that hydrolyzes arachidonate from the membrane phospholipids. This enzyme has not yet been identified in Aplysia neurons. Receptor-mediated stimulation of eicosanoid production in mammalian systems invariably depends on the release of free arachidonate. This rate-limiting reaction can be triggered by receptor-linked activation of phospholipase $A_{2}$, phospholipase $C$ followed by diacylglycerol lipase, or both (Irvine, 1982).

\section{Specificity of responses to various treatments}

Exposure of Aplysia neural components to histamine and stimulation of C2 or L32 neurons each resulted in considerably different patterns of eicosanoid production. Histamine, when applied to neural components from the cerebral ganglion, elic- ited formation of 12-HETE; with C2 stimulation, a product that we have tentatively identified as 5-HETE was the most abundant metabolite. We have not yet determined the reason for these differences. Nevertheless, there are many possible biological causes for these results that may be interesting and important. The endowment of enzymes in the 2 lipoxygenase pathways may vary in different neurons, or the enzymes might be differentially distributed among the different parts of all neurons (for example, cell body and nerve terminals). These explanations make use of differences in either cell type or accessibility, but other factors might also account for the puzzling differences observed. Interestingly, in mammals, 5-lipoxygenase activity is dependent on $\mathrm{Ca}^{2+}$, but 12-lipoxygenase is not (Rouzer and Samuelsson, 1985). Thus the same nerve cell might metabolize arachidonic acid differently depending on the concentration of intracellular $\mathrm{Ca}^{2+}$, which, in turn, would depend on its previous history with regard to synaptic inputs regulating $\mathrm{Ca}^{2+}$ channels and mobilization of $\mathrm{Ca}^{2+}$ from intracellular stores. The differences observed between the products formed in response to stimulating C2 and L32 could likewise be explained by differences in cell type or dependence on activity. In addition, it is important to caution that our cell-stimulation experiments were performed under conditions in which activation of a single neuron may have driven polysynaptic networks of unmonitored nerve cells. These networks would, of course, be different for the 2 identified neurons stimulated.

\section{Possible physiological function}

Application of histamine and stimulation of the histaminergic neuron $\mathrm{C} 2$ or neurons in the L32 cluster promote the formation of lipoxygenase products of arachidonic acid. These treatments share the common feature of causing presynaptic inhibition. Involvement of lipoxygenase products in presynaptic inhibition is also indicated by pharmacological experiments carried out on the identified Aplysia interneuron, Ll0 (Shapiro et al., 1987) and on Aplysia sensory cells (Piomelli et al., 1987a). In both cells, the responses to inhibitory transmitters are mimicked upon application of arachidonic acid and suppressed by 4-bromophenacyl bromide, a phospholipase inhibitor. The neuropeptide FMRFamide produces inhibition in Aplysia (Ocorr and Byrne, 1985; Brezina et al., 1987) and mediates presynaptic inhibition in sensory cells (Belardetti et al., 1987). NDGA, a lipoxygenase inhibitor, suppresses the membrane hyperpolarization elicited by FMRFamide, whereas indomethacin, a cyclooxygenase blocker, is without effect. The response to FMRFamide can also be mimicked by the lipoxygenase metabolite 12-HPETE, whereas its derivative, 12-HETE, is inactive. These observations suggest that a lipoxygenase metabolite of arachidonic acid, the hydroperoxy acid, or an unidentified metabolite mediates the inhibitory response to FMRFamide in Aplysia sensory neurons. Similarly, 12-HPETE was found to inhibit the release of renin from the juxtaglomerular cells in mammalian kidney at concentrations 100 times lower than that of 12-HETE (Antonipillai et al., 1987). In other cells, 12-HPETE and 5-HPETE have biochemical effects that are not shared by the corresponding HETE; for example, they stimulate formation of cGMP (Hidaka and Asano, 1977; Snider et al., 1984), which is also observed in Aplysia ganglia (Piomelli and Schwartz, unpublished observations). The hydroperoxy acids also inhibit prostacyclin synthase (Moncada and Vane, 1979) and stimulate leukotriene production (Maclouf et al., 1982), whereas the hydroxy acids do not. 
The ease with which both lipoxygenase and cyclo-oxygenase products pass through the neuronal membrane raises the question as to whether these compounds might mediate intercellular as well as intracellular signaling. Some hypotheses explaining synaptic plasticity underlying learning and memory make use of second-messenger mechanisms in the presynaptic terminal (see Kandel and Schwartz, 1982). Others would implicate changes in the postsynaptic neuron (see Teyler and DiScenna, 1987). These 2 kinds of mechanisms need not be mutually exclusive. Hedqvist (1977) showed that $\mathrm{PGE}_{2}$ released from adrenergic neurons in the sympathetic nervous system has an autocrine function. It is therefore possible that some metabolites of arachidonic acid act as intracellular second messengers (in the presynaptic element), while others pass through the terminal membrane and cross the cleft to act as first messengers on the postsynaptic cell.

\section{References}

Adesuyi, S. A., C. S. Cockrell, D. A. Gamache, and E. F. Ellis (1985) Lipoxygenase metabolism of arachidonic acid in brain. J. Neurochem. 45: 770-776.

Antonipillai, I., J. L. Nadler, E. C. Robin, and R. Horton (1987) The inhibitory role of 12- and 15-lipoxygenase products on renin release. Hypertension 10:61-66.

Baenziger, N. L., L. E. Force, and P. R. Becherer (1980) Histamine stimulates prostacyclin synthesis in cultured human umbilical vein endothelial cells. Biochem. Biophys. Res. Commun. 92: 1435-1440.

Belardetti, F., E. R. Kandel, and S. A. Siegelbaum (1987) Neuronal inhibition by the peptide FMRFamide involves opening of $\mathrm{S}-\mathrm{K}^{+}$ channels in Aplysia. Nature 325: 153-156.

Birkle, D. L., and N. G. Bazan (1984) Effect of $\mathrm{K}^{+}$depolarization on the synthesis of prostaglandins and hydroxy-eicosatetra$(5,8,11,14)$ enoic acids (HFTF) in the rat retina. Fvidence for esterification of 12-HETE in lipids. Biochim. Biophys. Acta 795: 564-573.

Birkle, D. L., and E. F. Ellis (1983) Conversion of arachidonic acid to cyclo-oxygenase products, and incorporation into phospholipids in the mouse neuroblastoma clone, neuro 2-A. Neurochem. Res. 8 : 319-332.

Blackwell, G. J., R. J. Flower, F. P. Nijkamp, and J. R. Vane (1978) Phospholipase $\mathrm{A}_{2}$ activity of guinea-pig isolated perfused lungs: Stimulation and inhibition by anti-inflammatory steroids. Br. J. Pharmacol. 62: 79-89.

Brezina, V., R. Eckert, and C. Erxleben (1987) Suppression of calcium current by an endogenous neuropeptide in neurones of Aplysia californica. J. Physiol. (Lond.) 382: 267-290.

Bryant, R. W., and J. M. Bailey (1979) Isolation of a new lipoxygenase metabolite of arachidonic acid, 8,11,12-trihydroxy-5,9,14-eicosatrienoic acid from human platelets. Prostaglandins 17:9-18.

Byrne, J. H. (1980a) Identification of neurons contributing to presynaptic inhibition in Aplysia californica. Brain Res. 199: 235-239.

Byrne, J. H. (1980b) Neural circuit for inking behavior in Aplysia californica. J. Neurophysiol. 43: 896-911.

Chiel, H. J., K. R. Weiss, and I. Kupfermann (1983) An identified histaminergic neuron acts pre- and post-synaptically to inhibit the outputs of identified buccal-cerebral interneurons. Soc. Neurosci. Abstr. 9: 913.

Chin, G., E. Shapiro, and J. H. Schwartz (1985) Release of transmitter from Aplysia synaptosomes. Soc. Neurosci. Abst. 11: 29.

Christ, E. J., and D. A. Van Dorp (1972) Comparative aspects of prostaglandin biosynthesis in animal tissues. Biochim. Biophys. Acta 270: $537-545$.

Connor, J. A., R. Kretz, and E. Shapiro (1986) Calcium levels measured in a presynaptic neurone of $A$ plysia under conditions that modulate transmitter release. J. Physiol. (Lond.) 375: 625-642.

Coughlin, S. R., M. A. Moskowitz, and L. Levine (1984) Identification of a serotonin type 2 receptor linked to prostacyclin synthesis in vascular smooth muscle cclls. Biochem. Pharmacol. 33: 692-695.

Eisenstadt, M., J. E. Goldman, E. R. Kandel, H. Koike, J. Koester, and J. H. Schwartz (1973) Intrasomatic injection of radioactive precursors for studying transmitter synthesis in identified neurons of Aplysia californica. Proc. Natl. Acad. Sci. USA 70: 3371-3375.
Eling, T., B. Tainer, A. Ally, and R. Warnock (1982) Separation of arachidonic acid metabolites by high pressure liquid chromatography. Methods Enzymol. 86: 511-517.

German, J. B., and J. E. Kinsella (1986) Production of trihydroxy derivatives of arachidonic acid and docosahexaenoic acid by lipoxygenase activity in trout gill tissue. Biochim. Biophys. Acta 877: 290298.

Giller, E., and J. H. Schwartz (1971) Choline acetyltransferase in identified neurons of abdominal ganglion of Aplysia californica. $\mathrm{J}$. Neurophysiol. 34: 93-107.

Granzow, B., and C. H. Fraser Rowell (1981) Further observations on the serotonergic cerebral neurones of Helisoma (Mollusca, Gastropoda): The case for homology with the metacerebral cclls. J. Exp. Biol. 90: 283-305.

Gruol, D. L., and D. Weinreich (1979) Two pharmacologically distinct histamine receptors mediating membrane hyperpolarization on identified neurons of Aplysia californica. Brain Res. 162: 281-301.

Hedqvist, P. (1977) Basic mechanisms of prostaglandin action on autonomic neurotransmission. Annu. Rev. Pharmacol. Toxicol. 17: 259-279.

Hidaka, H., and T. Asano (1977) Stimulation of human platelet guanylate cyclase by unsaturated fatty acid peroxides. Proc. Natl. Acad. Sci. USA 74: 3657-3661.

Hintzen, D. H., and J. Riehl (1985) Presynaptic inhibition in cerebral ganglion of Aplysia. Drug Res. 35: 292-297.

Irvine, R. F. (1982) How is the level of free arachidonic acid controlled in mammalian cells? Biochem. J. 204: 3-16.

Isay, S. V., and N. G. Burasova (1984) Study on fatty acid composition of marine organisms. I. Unsaturated fatty acids of Japan sea invertebrates. Comp. Biochem. Physiol. 77 B: 803-810.

Kandel, E. R., and J. H. Schwartz (1982) Molecular biology of learning: Modulation of transmitter release. Science 218: 433-443.

Komai, Y., S. Matsukawa, and M. Satake (1973) Lipid composition of the nervous tissue of the invertebrates Aplysia kurodai (gastropod) and Cambarus clarki (arthropod). Biochim. Biophys. Acta 316: 271281 .

Kretz, R., E. Shapiro, and E. R. Kandel (1986a) Presynaptic inhibition produced by an identified presynaptic inhibitory neuron. I. Physiological mechanisms. J. Neurophysiol. 55: 113-130.

Kretz, R., E. Shapiro, C. H. Bailey, M. Chen, and E. R. Kandel (1986b) Presynaptic inhibition produced by an identified presynaptic inhibitory neuron. II. Presynaptic conductance changes caused by histamine. J. Neurophysiol. 55: 131-146.

Kupfermann, I. (1979) Modulatory actions of neurotransmitters. Anunu. Rev. Neurosci. 2: 447-465.

Levine, L., and T. Kobayashi (1983) Detection of compounds immunologically related to arachidonic acid transformation products in extracts of invertebrates. Prostaglandins Leukotrienes Med. 12: 357369.

Lindgren, J. A., T. Hökfelt, S.-E. Dahlén, C. Patrono, and B. Samuelsson (1984) Leukotrienes in the rat central nervous system. Proc. Natl. Acad. Sci. USA 81: 6212-6216.

Maclouf, J., B. Fruteau de Laclos, and P. Borgeat (1982) Stimulation of leukotriene biosynthesis in human blood leukocytes by plateletderived 12-hydroperoxy-icosatetraenoic acid. Proc. Natl. Acad. Sci. USA 79: 6042-6046.

McCaman, R. E., and D. G. McKenna (1978) Monosynaptic connections between histamine-containing neurons and their various follower cells. Brain Res. 141: 165-171.

McCaman, R. E., and D. Weinreich (1982) On the nature of histaminemediated slow hyperpolarizing synaptic potentials in identified molluscan neurons. J. Physiol. (Lond.) 328: 485-507.

McCaman, R. E., and D. Weinreich (1985) Histaminergic synaptic transmission in the cerebral ganglion of Aplysia. J. Neurophysiol. 53: 1016-1037.

Moncada, S., and J. R. Vane (1979) Pharmacology and endogenous roles of prostaglandin endoperoxides, thromboxane $A_{2}$ and prostacyclin. Pharmacol. Rev. 30: 293-331.

Needleman, P., J. Turk, B. A. Jakschik, A. R. Morrison, and J. B. Lefkowith (1986) Arachidonic acid metabolism. Annu. Rev. Biochem. 55: 69-102.

Ocorr, K. A., and J. H. Byrne (1985) Membrane responses and changes in cAMP levels in Aplysia sensory neurons produced by serotonin, tryptamine, FMRFamide and small cardioactive peptide ${ }_{B}\left(\mathrm{SCP}_{\mathrm{B}}\right)$. Neurosci. Lett. 55: 113-118.

Pace-Asciak, C. R., E. Granström, and B. Samuelsson (1983) Arac- 
hidonic acid epoxides. Isolation and structure of two hydroxy epoxide intermediates in the formation of 8,11,12- and 10,11,12-trihydroxy eicosatrienoic acids. J. Biol. Chem. 258: 6835-6840.

Piomelli, D., S. J. Feinmark, E. Shapiro, and J. H. Schwartz (1986) Stimulation of $\mathrm{C} 2$, an identified histaminergic $A$ plysia neuron, results in increased release of lipoxygenase metabolites of arachidonic acid: Possible mediators of synaptic modulation. Soc. Neurosci. Abstr. 12 1340 .

Piomelli, D., S. J. Feinmark, and J. H. Schwartz (1987a) 12-hydroperoxyeicosatetraenoic acid (12-HPETE), a lipoxygenase metabolite of arachidonic acid that produces presynaptic inhibition in Aplysia, is metabolized to the hepoxilins $A$ and $B$ in neural tissues. Soc. Neurosci. Abstr. 13: 598.

Piomelli, D., A. Volterra, N. Dale, S. A. Siegelbaum, E. R. Kandel, J. H. Schwartz, and F. Belardetti (1987b) Lipoxygenase metabolites of arachidonic acid as second messengers for presynaptic inhibition of Aplysia sensory cells. Nature 328: 38-43.

Roots, B. I., and P. V. Johnston (1965) Lipids of isolated neurons. Biochem. J. 94: 61-63.

Rouzer, C. A., and B. Samuelsson (1985) On the nature of the 5-lipoxygenase reaction in human leukocytes: Enzyme purification and requirements for multiple stimulating factors. Proc. Natl. Acad. Sci. USA 82: 6040-6044.

Schwartz, J. H., A. Elste, E. Shapiro, and H. Gotoh (1986) Biochemical and morphological correlates of transmitter type in C2, an identified histaminergic neuron in Aplysia. J. Comp. Neurol. 245: 401-421.

Shapiro, E., D. Piomelli, and J. H. Schwartz (1987) Evidence that arachidonic acid cascade generates second messengers that mediate presynaptic inhibition in an identified cell circuit in Aplysia. Soc. Neurosci. Abstr. 13: 597.
Shimizu, T., Y. Takusagawa, T. Izumi, N. Ohishi, and Y. Seyama (1987) Enzymatic synthesis of leukotriene $B_{4}$ in guinea pig brain. J. Neurochem. 48: 1541-1546.

Snider, R. M., M. McKinney, C. Forray, and E. Richelson (1984) Neurotransmitter receptors mediate cyclic GMP formation by involvement of arachidonic acid and lipoxygenase. Proc. Natl. Acad. Sci. USA 81: 3905-3909.

Stenson, W. F., and C. W. Parker (1979) 12-L-Hydroxy-5,8,10,14eicosatetraenoic acid, a chemotactic fatty acid, is incorporated into neutrophil phospholipids and triglyceride. Prostaglandins 18: 285292.

Stryer, L., and H. R. Bourne (1986) G proteins: A family of signal transducers. Annu. Rev. Cell Biol. 2: 391-419.

Sutherland, E. W., and T. W. Rall (1960) The relation of adenosine $3^{\prime}-5^{\prime}$-phosphate and phosphorylase to the actions of catecholamines and other hormones. Pharmacol. Rev. 12: 265.

Teyler, T. J., and P. DiScenna (1987) Long-term potentiation. Annu. Rev. Neurosci. 10: 131-161.

Van den Busch, H. (1980) Intracellular phospholipases A. Biochim. Biophys. Acta 604: 191-246.

Voogt, P. A. (1972) Lipid and sterol components and metabolism in mollusca. In Chemical Zoology, M. Florkin and B. T. Scheer, eds., pp. 245-300, Academic, New York.

Weinreich, D., C. Weiner, and R. E. McCaman (1975) Endogenous levels of histamine in single neurons isolated from CNS of Aplysia californica. Brain Res. 84: 341-345.

Wolfe, I. S. (1982) Eicosanoids: Prostaglandins, thromboxanes, leukotrienes, and other derivatives of carbon-20 unsaturated fatty acids. J. Neurochem. 38: 1-14. 